\title{
Towards a critical theory of information
}

\author{
Christian Fuchs
}

Unified Theory of Information Research Group; University of Salzburg, ICT\&S Center, Sigmund Haffner Gasse 18, A-5020 Salzburg, Austria.

E-mail: Christian.fuchs@sbg.ac.at Web:<http://fuchs.icts.sbg.ac.at>, <http://fuchs.uti.at>

\begin{abstract}
Critical information theory is an endeavour that focuses ontologically on the analysis of information in the context of domination, asymmetrical power relations, exploitation, oppression, and control by employing epistemologically all theoretical and/or empirical means necessary for doing so in order to contribute at the praxeological level to the establishment of a participatory, co-operative society. Three foundational aspects of a critical theory of information are discussed in this paper: the relation of immanence and transcendence, the relation of base and superstructure, and ideology critique.

The logical figure of immanent transcendence is based on the dialectic of essence and existence and poses a viable counterpart to positivistic and postmodern definitions of critique. As an example for the logic of immanent transcendence to critical information theory, a contradiction of the Internet economy is discussed.

The debate on redistribution and recognition between critical theorists Nancy Fraser and Axel Honneth gives the opportunity to renew the discussion of the relationship of base and superstructure in critical social theory. Critical information theory needs to be aware of economic, political, and cultural demands that it needs to make in struggles for ending domination and oppression, and of the unifying role that the economy and class play in these demands and struggles. Objective and subjective information concepts are based on the underlying worldview of reification. Reification endangers human existence. Information as process and relation enables political and ethical alternatives that have radical implications for society.
\end{abstract}

Keywords: critical theory, information, information society, social theory

Acknowledgement: This paper was originally published as: Fuchs, Christian (2008). Towards a Critical Theory of Information. In: Díaz Nafria, J. M. \& Salto Alemany, F. (Ed.) (2008) Qué es Información? (What is Information? Proceedings of the First International Meeting of Experts in Information Theories. An Interdisciplinary Approach, November 6-7, 2008). León, Spain: Universidad de León. ISBN: 978-84-9773-451-6. pp. 247-316.

$\mathrm{T}$ he basic idea of this contribution is to reflect on how the notion of critical theory could be applied to information studies. What does it mean to study information in a critical way? As an introduction, I will start with a problem in order to show why exactly a critical theory of information is needed.

\section{Introduction}

Edwin Black (2001) in his book IBM and the Holocaust has shown that International Business Machines (IBM) assisted the Nazis in their attempt to extinguish the Jews, ethnic minorities, communists, socialists, gay people, the handicapped, and others by selling punch card systems to them ${ }^{1}$. These systems were used for numbering the victims, storing and processing where they should be brought, what should happen to them, and for organizing their transport to extermination camps such as Auschwitz, Bergen-Belsen, Buchenwald, Dachau, Majdanek, Mauthausen, Ravensbrück, or Sachsenhausen. IBM made an international business out of mass killings by making profits from selling data

1 See also the scene on IBM in the film "The Corporation" by Mark Achbar and Jennifer Abbott (Big Picture Media 2004, available on DVD), http://de.youtube.com/watch?v=pkoM8RB-kJ0 (accessed on August 19, 2008). 
storage and processing machines to the Nazis. The punch cards covered information on where a victim would be deported, the type of victim he/she was (Jew, homosexual, deserter, prisoners of war, etc), and his/her status. Code status 6 was "Sonderbehandlung" (special treatment), which meant death in the gas chamber. Black has shown that the system was delivered and maintained by IBM and that rental contracts between IBM New York and the German Nazi state were made. Black (2001, p. 9) says that there was a "conscious involvement -directly and through its subsidiaries-" of IBM "in the Holocaust, as well as (...) in the Nazi war machine that murdered millions of others throughout Europe". "Solipsistic and dazzled by its own swirling universe of technical possibilities, IBM was self-gripped by a special amoral corporate mantra: if it can be done, it should be done. To the blind technocrat, the means were more important than the ends. The destruction of the Jewish people became even less important because the invigorating nature of IBM's technical achievement was only heightened by the fantastical profits to be made at a time when bread lines stretched across the world" (Black, 2001, p. 10).

Irving Wladawsky-Berger, then IBM's vice president of technical strategy, commented on Black's book: "Generally, you sell computers, and they are used in a variety of ways. And you hope they are using the more positive ways possible"2. The example shows that corporations in general, and information technology corporations like IBM in particular, are driven by profit interests and will support the worst horrors if they can draw economic profits from it. Wladawsky-Berger's reaction is a typical one: Corporations that have committed moral crimes against humanity argue that they are not responsible for what their customers do with the commodities they sell to them. Critical reasoning such as the one by Edwin Black intends to show in this context that corporations are not always unknowing of what is going on and do have responsibility that they abandon in many cases due to their instrumental interests. The

\footnotetext{
${ }^{2}$ Interview in "The Corporation", film by Mark Achbar and Jennifer Abbott (Big Picture Media 2004, available on DVD).
}

example also shows that media and the communication industry are not innocent, but deeply embedded into structures of domination. And this is exactly the reason why a critical theory of information is needed. Karl Marx summarized the imperatives and convictions of corporations in the following words: "Accumulate, accumulate! That is Moses and the prophets! (...) Therefore, save, save, i.e, reconvert the greatest possible portion of surplus-value, or surplus-product into capital! Accumulation for accumulation's sake, production for production's sake: by this formula classical economy expressed the historical mission of the bourgeoisie" (MECW 35 , p. 652). The accumulation imperative stops at nothing.

First, the notion of critical theory will be discussed (section 2). Then the problem of immanence and transcendence in critical theory will be introduced (section 3), the debate on redistribution and recognition in critical theory will be considered (section 4), and finally some critical reflections on the notion of information will be given (section 5).

\section{What is critical theory?}

Certainly all scholars want to be and claim to be critical. It seems to me that critique is one of the most inflationary used terms in academia. This issue was already at the heart of the positivism debate in German sociology in 1961. For Karl R. Popper (1962) the method of the social sciences is gaining and differentiating knowledge by testing solutions to problems. This method would be critical because scholars would question the works of others in order to improve knowledge in trial and error processes. For Popper critique is an epistemological method that shows logical contradictions. Theodor W. Adorno (1962) argues that contradictions are not only epistemological (in the relation of subjectobject), but can be inherent in objects themselves so that they cannot be resolved by acquiring new knowledge (Adorno, 1962, p. 551). Adorno stresses that Popper's ideal of value-free science is shaped by the bourgeois concept of value as exchange value (Adorno, 1962, p. 560). He says that positivism is only oriented on appearance, whereas Critical Theory stresses the 
difference between essence and appearance (Adorno, 1969, p. 291). He points out that Popper's notion of critique is subjective and cognitive (Adorno, 1969, p. 304).

So there is a fundamental difference between epistemological critique (Popper) and the critique of society (Adorno). I argue that it is the second understanding that should be used for defining a critical theory of information and that therefore there is also a whole lot of uncritical thinking in information studies. One might as well argue that based on Horkheimer (1937/2002) a distinction between traditional and critical information studies/theories is necessary.

Paul F. Lazarsfeld (1941/2004, p. 169) argued that critical research in Horkheimer's sense "seems to be distinguished from administrative research in two respects: it develops a theory of the prevailing social trends of our times, general trends which yet require consideration in any concrete research problem; and it seems to imply ideas of basic human values according to which all actual or desired effects should be appraised".

Although Lazarsfeld sees that contemporary society is a "period of increasing centralization of ownership" ( $p$. 169) shaped by the "technique of manipulating large masses of people" (p. 169) and the development towards a "promotional culture" (p. 171), it does not suffice to argue that critical communications research means that "the general role of our media of communication in the present social system should be studied" (p. 169) and that a normative position is taken, because this means that e.g. normative research that argues for the prohibition of trade unions or abortion or for the reintroduction of slavery must also be seen as critical. Critical information theory therefore must study not just the role of information and information concepts in society, academia, nature, culture, etc, but how it is related to processes of oppression, exploitation, and domination, which implies a normative judgment in solidarity with the dominated and for the abolishment of domination.

Dallas Smythe and Tran van Dinh (1983, p. 117) are therefore right in arguing that in distinguishing administrative from critical research besides these two factors "a third factor is also involved: the ideological orientation of the researcher". "By 'administrative' researchable problems we mean how to make an organization's actions more efficient, e.g., how best to advertise a brand of toothpaste, how most profitably to innovate word processors and video display terminals within a corporation, etc. By 'critical' researchable problems we mean how to reshape or invent institutions to meet the collective needs of the relevant social community, through devices such as direct broadcast satellites, terrestrial broadcast stations and networks, and cable TV, or, at a 'micro' level, how to conduct psychotherapy and how to study rumors. By 'administrative' tools, we refer to applications of neopositivist, behavioral theory to the end of divining effects on individuals. By 'critical' tools, we refer to historical, materialist analysis of the contradictory process in the real world. By 'administrative' ideology, we mean the linking of administrative-type problems and tools, with interpretation of results that supports, or does not seriously disturb, the status quo. By 'critical' ideology, we refer to the linking of 'critical' researchable problems and critical tools with interpretations that involve radical changes in the established order" (Smythe/Dinh, 1983, p. 118). The important stress here is that critical communication research has the goal of "radical changes in the established order". Eileen Meehan (1999, p. 150) termed administrative communication research "celebratory research", arguing: "If we begin with a shared valuation that 'although some problems may exist, capitalism is fundamentally good', our research thereby takes a celebratory stance toward media products, audiences, and institutions. If our shared valuation suggests that 'despite some progress, capitalism is fundamentally flawed', a critical stance is an integral part of our research. Attempts at dialogue across these mutually exclusive valuations seem bound to fail".

This debate suggests that critical information theory should be considered as having a normative dimension that aims at fostering research on and theories of information that can help advance the public good. 
A recent debate in American sociology on critical and public science can in my opinion positively inform the discussion on critical information theory.

Michael Burawoy (2005a, b, 2007) argues that neoliberalism has resulted in the privatization of everything. As a consequence, conducting public social science that tackles real world problems would become ever more important as society would become more precarious and reactionary. In the 1970s, the social sciences would have lagged behind the radical character of social movements and therefore the task would have been to create a critical academic science. Today, society would be more reactionary, and society would lag behind academia. Therefore the primary task for academia would be to transform society. In traditional public sciences, scholars would write in the opinion pages of national newspapers. In organic public sciences, scholars would work "in close connection with a visible, thick, active, local, and often counterpublic" (Burawoy, 2007, p. 28).

"Policy sociology is sociology in the service of a goal defined by a client. (....) Professional sociology (...) supplies true and tested methods, accumulated bodies of knowledge, orienting questions, and conceptual frameworks. (...) Professional sociology consists first and foremost of multiple intersecting research programs (...) Critical sociology attempts to make professional sociology aware of its biases and silences, promoting new research programs built on alternative foundations. Critical sociology is the conscience of professional sociology, just as public sociology is the conscience of policy sociology. (...) Public sociology brings sociology into a conversation with publics" (Burawoy, 2007, pp. 31, 32, 33, 28). "Critical sociology is a normative dialogue, primarily among sociologists and conventionally directed to professional sociology, whereas public sociology is dialogue primarily between sociologists and publics about the normative foundations of society" (Burawoy, 2005a, p. 380).

This distinction is based on two questions: Science for what (instrumental knowledge or reflexive knowledge)? Science for whom (academic audience or extra-academic audience)? Burawoy bases the first distinction on Horkheimer and Adorno (Burawoy, 2007, p. 34). Instrumental knowledge would be oriented on means to reach ends, whereas reflexive knowledge would be concerned with the ends of society. This means that reflexive knowledge is inherently ethical, political, and partisan.

Table 1: Michael Burawoy's typology of social science approaches

\begin{tabular}{|c|c|c|}
\hline & $\begin{array}{l}\text { Academic } \\
\text { Audience }\end{array}$ & $\begin{array}{l}\text { Extra-academic } \\
\text { Audience }\end{array}$ \\
\hline $\begin{array}{l}\text { Instrumental } \\
\text { knowledge }\end{array}$ & $\begin{array}{l}\text { Professional } \\
\text { Sciences: } \\
\text { research } \\
\text { conducted within } \\
\text { research } \\
\text { programs that } \\
\text { define } \\
\text { assumptions, } \\
\text { theories, } \\
\text { concepts, } \\
\text { questions, and } \\
\text { puzzles }\end{array}$ & $\begin{array}{l}\text { Policy Sciences: } \\
\text { public defence of } \\
\text { research, human } \\
\text { subjects, funding, } \\
\text { congressional } \\
\text { briefings }\end{array}$ \\
\hline $\begin{array}{l}\text { Reflexive } \\
\text { knowledge }\end{array}$ & $\begin{array}{l}\text { Critical Sciences: } \\
\text { critical debates of } \\
\text { disciplines within } \\
\text { and between } \\
\text { research } \\
\text { programs }\end{array}$ & $\begin{array}{l}\text { Public Sciences: } \\
\text { concern for the } \\
\text { public image of } \\
\text { the sciences, } \\
\text { presenting } \\
\text { findings in an } \\
\text { accessible } \\
\text { manner, teaching } \\
\text { basics of science, } \\
\text { and writing } \\
\text { textbooks }\end{array}$ \\
\hline
\end{tabular}

Burawoy argues: "Public sociology has no intrinsic normative valences, other than the commitment to dialogue around issues raised in and by sociology. It can as well support Christian fundamentalism as it can liberation sociology or communitarianism" (Burawoy. 2007, p. 30).

For Max Horkheimer, the distinction was not between instrumental reason and reflexive reason, but between instrumental reason and critical reason. He termed academic thinking that is based on the first traditional theory, and academic thinking that is based on the latter critical theory (Horkheimer, 1937/2002). He also made clear that the second type of reason is not just any type of normativity and partisanship, but a specific kind of it. For Horkheimer it does not suffice to ask questions or to address the public. Instrumental reason would be oriented on 
utility, profitableness, and productivity. Critical reason would be partisan and would operate with the Marxian categories of class, exploitation, surplus value, profit, misery, and breakdown. These categories would constitute a whole that is not oriented on "the preservation of contemporary society but in its transformation into the right kind of society" (Horkheimer, 1937/2002, p. 218). The goal of critical theory would be the transformation of society as a whole (p. 219) so that a "society without injustice" (p. 221) emerges that is shaped by "reasonableness, and striving for peace, freedom, and happiness" (p. 222), "in which man's actions no longer flow from a mechanism but from his own decision" ( $p$. 229 ), and that is "a state of affairs in which there will be no exploitation or oppression" ( $p$. 241).

Horkheimer argued that critical theory wants to enhance the realization of all human potentialities (p. 248). It "never simply aims at an increase of knowledge as such. Its goal is man's emancipation from slavery" (p. 249) and "the happiness of all individuals" (p. 248).

These quotations show that for Horkheimer critical and public academic work is not just normative, partial, and addressing the public, it is partial for the oppressed, demands their emancipation from oppression, and opposes and fights with intellectual means against those classes that are responsible for this oppression. Critical theory is intellectual class struggle. It is anti-capitalist and opposed to domination. It struggles for a classless, nondominative, co-operative, participatory democracy. Instrumental reason is for Horkheimer (1947/1974) the dominant type of rationality, in which reason becomes an instrument for advancing external, dominative, alienating interests. In an instrumental society, the human beings would not be themselves, but serve alien interests. In critical rationality, humans would be self-determined and be themselves.

Sciences that support Christian fundamentalism are for Horkheimer a false form of partisanship and a form of public science that supports a dominative and instrumental society. It is based on instrumental reason. It is therefore part of instrumental policy science and not of reflexive public science. What are needed are not just public sciences, but critical, Marxian-inspired, left wing, progressive public sciences in Horkheimer's sense. I therefore agree with Francis Fox Piven (2007), who argues for a "dissident and critical public sociology". Public sciences should not only speak to the public, but to a specific public. "I propose as a guideline that we strive to address the public and political problems of people of the lower end of hierarchies that define our society. (...) Their felt problems should become our sociological problems. If we do this, then public sociology becomes a dissident and critical sociology" (Fox Piven, 2007, p. 163).

Based on these assumptions, I want to further develop Burawoy's typology into a Horkheimerian direction. The notion of critique employed in it is not just a critique of dominant academic traditions, but rather critique of dominative society and class structuration as such. The public sciences envisioned here constitute a strong form of Burawoy's public sciences - a strong objectivity that should best be termed public critical sciences and that are opposed by and to the now-dominant public uncritical sciences. In the purely academic world, critical sciences challenge the dominant uncritical, positivistic professional instrumental sciences. What Burawoy defines as academic socialism should be stressed more explicitly as the desirable form of the public sciences, whereas instrumental public sciences that advance dominative interests should be seen as undesirable. "We might say that critical engagement with real utopias is today an integral part of the project of sociological socialism. It is a vision of a socialism that places society, or social humanity at its organizing center. (...) If public sociology is to have a progressive impact it will have to hold itself continuously accountable to some such vision of democratic socialism" (Burawoy, 2005b, p. 325). Burawoy's distinction between traditional and organic public science does not account for Horkheimer's insight that the first type is based on instrumental reason and is undesirable. 
Table 2: A typology of instrumental and critical social sciences

\begin{tabular}{|c|c|c|}
\hline & $\begin{array}{l}\text { Academic } \\
\text { Audience }\end{array}$ & $\begin{array}{l}\text { Extra-academic } \\
\text { Audience }\end{array}$ \\
\hline $\begin{array}{l}\text { Instrumental } \\
\text { knowledge }\end{array}$ & $\begin{array}{l}\text { Professional } \\
\text { instrumental } \\
\text { sciences: } \\
\text { research } \\
\text { conducted within } \\
\text { research programs } \\
\text { that are shaped by } \\
\text { dominative } \\
\text { interests. }\end{array}$ & $\begin{array}{l}\text { Public uncritical } \\
\text { sciences: sciences } \\
\text { that speak with the } \\
\text { public in the } \\
\text { interest of } \\
\text { dominative } \\
\text { interests such as } \\
\text { capital interests or } \\
\text { conservative } \\
\text { political interests. }\end{array}$ \\
\hline $\begin{array}{l}\text { Critical } \\
\text { knowledge }\end{array}$ & $\begin{array}{l}\text { Critical sciences: } \\
\text { analyses } \\
\text { conducted in the } \\
\text { interest of the } \\
\text { abolishment of } \\
\text { domination and the } \\
\text { establishment of } \\
\text { participatory } \\
\text { democracy. }\end{array}$ & $\begin{array}{l}\text { Public critical } \\
\text { sciences: sciences } \\
\text { that address and } \\
\text { speak with the } \\
\text { public in the } \\
\text { interest of the } \\
\text { abolishment of } \\
\text { domination and the } \\
\text { establishment of } \\
\text { participatory } \\
\text { democracy. }\end{array}$ \\
\hline
\end{tabular}

This typology can also be applied to information studies/theory.

If there is no counter-public because protest and activism are ideologically forestalled, then public sciences as public criticism still are necessary. Such knowledge does not and should not necessarily depend on the existence of a large number of activists and social movement groups - although this is desirable, but not always possible -, because this would silence critical academia once citizens are silenced. Academia certainly possesses resources that better equip scholars to act critically and that better protect them from being silenced than ordinary citizens. Therefore this terrain should make use of its privileged position to struggle and try to create a critical public no matter how the general public looks like. "It is possible for the consciousness of every social stratum today to be limited and corrupted by ideology, however much, for its circumstances, it may be bent on truth. For all its insight into the individual steps in social change and for all the agreement of its elements with the most advanced traditional theories, the critical theory has no specific influence on its side, except concern for the abolition of social injustice" (Horkheimer 1937/2002, p. 242).
Table 3: A typology of instrumental and critical communication science

\begin{tabular}{|c|c|c|}
\hline & $\begin{array}{l}\text { Academic } \\
\text { Audience }\end{array}$ & $\begin{array}{c}\text { Extra-Academic } \\
\text { Audience }\end{array}$ \\
\hline $\begin{array}{l}\text { Instrumental } \\
\text { Knowledge }\end{array}$ & $\begin{array}{l}\text { Professional } \\
\text { Instrumental } \\
\text { Information } \\
\text { Science/Theory: } \\
\text { Research on } \\
\text { information within } \\
\text { research programs } \\
\text { that are shaped by } \\
\text { dominative } \\
\text { interests. }\end{array}$ & $\begin{array}{l}\text { Public Uncritical } \\
\text { Information } \\
\text { Science/Theory: } \\
\text { Studies of } \\
\text { information } \\
\text { phenomena that } \\
\text { speak with the } \\
\text { public in the } \\
\text { interest of } \\
\text { dominative } \\
\text { interests such as } \\
\text { capital interests or } \\
\text { conservative } \\
\text { political interests. }\end{array}$ \\
\hline $\begin{array}{l}\text { Critical } \\
\text { Knowledge }\end{array}$ & $\begin{array}{l}\text { Critical } \\
\text { Information } \\
\text { Science/Theory: } \\
\text { Analyses of } \\
\text { information in the } \\
\text { context of } \\
\text { domination, } \\
\text { asymmetrical } \\
\text { power relations, } \\
\text { and control } \\
\text { conducted in the } \\
\text { interest of the } \\
\text { abolishment of } \\
\text { domination and the } \\
\text { establishment of } \\
\text { participatory } \\
\text { democracy. }\end{array}$ & $\begin{array}{l}\text { Public Critical } \\
\text { Information } \\
\text { Science/Theory: } \\
\text { Addresses and } \\
\text { speaks with the } \\
\text { public on issues } \\
\text { that relate to } \\
\text { information in the } \\
\text { context of } \\
\text { domination and in } \\
\text { the interest of the } \\
\text { abolishment of } \\
\text { domination and the } \\
\text { establishment of } \\
\text { participatory } \\
\text { democracy. }\end{array}$ \\
\hline
\end{tabular}

Burawoy argues that due to power constellations and powerful interests instrumental sciences dominate over reflexive sciences. The sciences would be fields of power. But this field of power should not be the ultimately accepted state of the sciences. One should struggle for the end of the division of labour so that all sciences become critical and therefore non-instrumental. The goal then is a unified critical science. Dialectical negation is not just the struggle for the acknowledgement of the other, but also the struggle for negation of negation and sublation so that a new whole that is a differentiated unity of plurality can emerge. Burawoy dismisses such arguments, saying that the social sciences "since their very definition (...) partake in both instrumental and reflexive knowledge" (Burawoy, 2007, p. 53). Horkheimer and Adorno (1944/2002) have pointed out that instrumental reason is characteristic for dominative, class societies because mechanisms for legitimizing and 
knowledge for enforcing alienation and exploitation are needed. If this is the case, then instrumental academic knowledge has a historical character and should come to an end once instrumental society comes to an end. Burawoy essentializes the division of labour of the contemporary sciences. Critical thinkers in many cases are discriminated by dominant institutions and therefore have to worry about attaining degrees, tenure, professorships, research funds, etc. Given the domination of instrumental reason in the academic system, it is not so easy to establish the structural foundations that enable engaging critically in the public. Therefore the liberal democratic pluralism of the academic system that Burawoy envisions is worth struggling for in the first instance. But one should not stop there, but also struggle for the establishment of an academic system that is no longer instrumental at all. The struggle for a non-instrumental academic system is at the same time the struggle for a non-instrumental society and vice versa. Immanuel Wallerstein (2007) argues that all science has an intellectual, a moral, and a political function and that all scholars are always doing all three functions. The ideology of instrumental positivistic sciences is that they deny the second and the third function, whereas critical sciences deconstruct this ideology, they are partisan in favour of the oppressed. Their partisanship is active. All three functions "are always being done, whether actively or passively. And doing them actively has the benefit of honesty and permitting open debate about substantive rationality" (Wallerstein, 2007 , p. 174). The ultimate goal should not be a division of academic labour with equal subfields based on liberal pluralism, but unified critical academic and public information studies within a unified critical academic and public science.

If reflexive or critical sciences are just understood as a critique of dominant sciences that provides alternative outlooks, then this means that if progressive social sciences are dominant, one should support conservative and reactionary approaches for the sake of pluralism. My argument counter to that is that politically conservative approaches and instrumental sciences should not be supported, but eliminated, and that the goal is not liberal pluralism, but the overall critical character of the sciences, i.e. sciences oriented on societal problems and the advancement of participatory democracy.

This discussion shows that critical theory has a focus on the analysis of phenomena in the context of domination, asymmetrical power relations, exploitation, oppression, and control as object of study. Such analyses are undertaken with all intellectual means necessary in order to contribute to the establishment of a participatory, co-operative society. From a praxeo-onto-epistemological perspective on science (cf. Hofkirchner, Fuchs, \& Klauninger, 2005, pp. 78-81), we can then define critical information theory/studies as an endeavour that focuses ontologically on the analysis of information in the context of domination, asymmetrical power relations, exploitation, oppression, and control by employing epistemologically all theoretical and/or empirical means necessary for doing so in order to contribute at the praxeological level to the establishment of a participatory, co-operative society. Given such a definition, critical information theory is inherently normative and political.

Critical information theory as critique of domination in the context of media, culture, and communication correspond perfectly to the understanding of critique given by Marx in the Introduction to the Critique of Hegel's Philosophy of Right in 1844: "Theory is capable of gripping the masses as soon as it demonstrates ad hominem, and it demonstrates ad hominem as soon as it becomes radical. To be radical is to grasp the root of the matter. But, for man, the root is man himself. (...) The criticism of religion ends with the teaching that man is the highest essence for man - hence, with the categoric imperative to overthrow all relations in which man is a debased, enslaved, abandoned, despicable essence, relations which cannot be better described than by the cry of a Frenchman when it was planned to introduce a tax on dogs: Poor dogs! They want to treat you as human beings!" (MEW 1, p. $385^{3}$ ).

\footnotetext{
${ }^{3}$ Translation from:

http://www.marxists.org/archive/marx/works/1843/critiquehpr/intro.htm (September 30, 2008).
} 
If we understand Marxian critique as the critique of all forms of domination and all dominative relationships, then all critical information studies are at least Marxianinspired. My argument is that this heritage should not be denied, but taken serious and positively acknowledged.

We can identify three important elements of the Marxian-inspired notion of critique:

- Epistemology - Dialectical Realism: The material world is seen as primary and is grasped, described, analyzed, and partly transformed by humans in academic work. Analyses are conducted that are looking for the essence of societal existence by identifying contradictions that lie at the heart of development. Critical theory analyzes social phenomena not based on instrumental reason and one-dimensional logic, i.e. it operates: 1. With the assumption that phenomena do not have linear causes and effects, but are contradictory, open, dynamic, and carry certain development potentials in them and hence should be conceived in complex forms; 2. Based on the insight that reality should be conceived so that there are neither only opportunities nor only risks inherent in social phenomena, but contradictory tendencies that pose both positive and negative potentials at the same time that are realized or suppressed by human social practice.

Dialectic analysis in this context means complex dynamic thinking, realism an analysis of real possibilities and a dialectic of pessimism and optimism. In a dialectical analysis, phenomena are analyzed in terms of the dialectics of agency and structures, discontinuity and continuity, the one and the many, potentiality and actuality, global and local, virtual and real, optimism and pessimism, essence and existence, immanence and transcendence, etc.

- Ontology - Materialism: Critical theory is materialistic in the sense that it addresses phenomena and problems not in terms of absolute ideas and predetermined societal development, but in terms of resource distribution and social struggles. Reality is seen in terms that address ownership, private property, resource distribution, social struggles, power, resource control, exploitation, and domination. In such an endeavour a reactualized notion of class is of central importance (cf. Fuchs, 2008, chapter 7.3).

To make a materialistic analysis also means to conceive society as negativity, to identify antagonisms means to take a look at contradictory tendencies that relate to one and the same phenomenon, create societal problems and require a fundamental systemic change in order to be dissolved. To analyze society as contradictory also means to consider it as dynamic system because contradictions cause development and movement of matter.

In order to address the negativity of contemporary society and its potential, research also needs to be oriented on the totality. That dialectics is a philosophy of totality in this context means that society is analyzed on a macro-scale in order to grasp its problems and that reasons for the necessity of positive transformations are to be given.

- Axiology - Negating the negative: All critical approaches in one or the other respect take the standpoint of oppressed or exploited classes and individuals and make the judgement that structures of oppression and exploitation benefit certain classes at the expense of others and hence should be radically transformed by social struggles. This view constitutes a form of objectivity. Critical theory does not accept existing social structures as they are, it is not purely focused society as it is, but interested in what it could be and could become. It deconstructs ideologies that claim that something cannot be changed and shows potential counter-tendencies and alternative modes of development. That the negative antagonisms are sublated into positive results is not an automatism, but depends on the realization of practical forces of change that have a potential to rise from the inside of the systems in question in order to produce a transcendental outside 
that becomes a new whole. The axiological dimension of critique is an interface between theory and political praxis.

Critical theory "opens more space for considering the possibility that the world could be different than it is" (Calhoun, 1995, p. 290).

So critical theory tries to uncover unrealized potentials of society. Hegel and Marx saw alienation theory as the analysis of the nonidentity of essence and existence of society and the realization of society's essence as the goal of society. Therefore Marx speaks of revolutionary transformation as "reintegration or return of man to himself, the transcendence of human self-estrangement", and "the real appropriation of the human essence by and for man ". "Communism (is) therefore (...) the complete return of man to himself as a social (i.e., human) being " (MEW 40, p. 536). So also given Calhouns definition of critical theory, one must see all critical social theory is (at least) Marxian-inspired. "Marx took much more seriously than most postmodernists what it would mean to transcend an epoch. We need to follow every specific of his theory to learn from him a similar seriousness" (Calhoun, 1995, p. 289). Critical theory would by "taking serious the question of what it would mean to transcend the current epoch" open "more space for considering the possibility that the world could be different than it is" (Calhoun, 1995, p. 290).

Alex Demirovic (2003b, 2007) sees interdisciplinarity, historicity of theory, and the unfolding of critique in the form of models as three characteristics of Frankfurt school critical theory. Critical theory would see concrete phenomena in the context of the critique of society as a whole and try to show how society as a whole shapes these phenomena and how and to which extent conditions for freedom, reason, pleasure, happiness, and free time develop for all (Demirovic, 2004b). Questions about who controls the means of production would have been very important for critical theory, but not determining aspects of society (Demirovic, $2004 a$, p. 479). Marx would have seen capitalism as a whole that is constituted by autonomous parts (Demirovic, 2004b, p. 480). I agree with Demirovic that the economy does not determine society, but to assume that society consists of autonomous parts means to argue for a plurality without unity. Counter to this view, I suggest to see the economy as a dominant system that is necessary for all other systems and unites the plurality that these systems give to society by giving them a unified logic (the one of accumulation in capitalist society) (Fuchs, 2008).

Wolfgang Bonß (2003) sees empirical critique, immanent critique, and normative critique (the critique that society could and should be other and better than it is) as three versions of critique. Newer forms of critique, such as the theories by Ulrich Beck and Scott Lash, would have dropped the normative element of critical theory, which would result in the renouncement of the idea of a critique of society.

David Rasmussen (1999) argues that that Marx had a deterministic, teleological philosophy of history. Horkheimer would have partly questioned this view in his essay Traditional and Critical Theory, but would have also held on to aspects of Marxism such as economic determinism, class analysis, and the possibility of revolution. Horkheimer and Adorno would have completely broken with this Marxist eschatology in The Dialectic of the Enlightenment by arguing that rationality must result in a negative history of domination. Adorno would have later partly saved the notion of rationality by arguing for the possibility of an alternative form of rationality in art. But only Habermas would have succeeded in combining the critique of rationality with the early Horkheimerian demand for an emancipatory rationality by introducing his notion of communicative rationality. "If the claims of critical theory can be rehabilitated on a transcendental level as the claims of a philosophy of language, then it would appear that philosophy as such can be defined vis-à-vis a theory of communicative action" (Rasmussen, 1999, p. 36).

Such a strong focus on critical theory understood as Habermasian discourse ethics, as presented by Rasmussen, has been challenged as reformist by other scholars. William Wilkerson and Jeffrey Paris (2001) in their edited collection New Critical Theory: Essays on Liberation advocate a new critical theory. The account is contradictory. On the 
one hand the author of the preface speaks in favour of a postmodern theory that focuses on the "anti-imperialist, receptive, open, and radically pluralized nature of refusals" (Matustik, 2001, p. xi). This position is also confirmed by the two editors who argue in their introduction that they accept "the ideal of dynamic and highly mediated relations between partial and disunited attempts to think the whole" (Wilkerson \& Paris, 2001, p. 2 ), that no grand unified theory of all of society should be sought, that plural voices are important, and that there is no necessary need to refer to Hegel, Marx, and Weber. On the other hand, some contributions in the book, such as the ones by the two editors, contradict this position (Paris, 2001; Wilkerson, 2001). Jeffrey Paris, one of the two editors, argues that Habermasian critical theory and postmodernism have lost the "oppositional spirit of critical theory" and engaged in a "tacit legitimation of the existing state of affairs" (Paris, 2001, p. 27). It would be necessary for critical theory to pose radical alternatives and to "enact the negation of current systems of exploitation and greed" (Paris, 2001, p. 31). William Wilkerson, the other editor, says that new critical theory "seeks liberation from domination and alienation" (Wilkerson, 2001, p. 70). James Marsh says that postmodernism and Habermasian theory are not "truly radical, critical social theory", but "a liberal tinkering with a New World Order" (Marsh, 2001, p. 50). New critical theory would have to point toward social transformation and democratic socialism. Marx would today be more relevant than ever. "Habermasian critical theory, we could say, to a great extent is a critical theory without Marx and is thus a critical theory that is insufficiently critical" (Marsh, 2001, p. 57). This tension between a modest, reformist, postmodern, pluralist position and a radical, revolutionary, Marxist position on how to define critical theory might be due to the fact that two different versions of critical theory have been included in the book, and that the least common denominator presented in the introduction has been the postmodern position. Paris, Wilkerson, and Marsh in contrast argue for a radical, revolutionary, Marxist critical theory and use the term new critical theory for this endeavour. They stress the importance of Marx and Marcuse for achieving this goal. In my opinion this term is not wisely chosen because novelty has become a postmodern ideology itself that tries to present radicalism and revolution as outdated and contemporary capitalist society as fundamentally novel. Therefore I would rather speak of the need of a reconstruction of Marxian thinking and a return to the original definition of critical theory given by Marcuse (1937b) and Horkheimer (1937/2002).

Applying critical theory to information can be characterized along the three dimensions of critical theory:

- Epistemology - Dialectical Realism: A theory of information that is dialectical and realistic identifies antagonistic tendencies of information phenomena. Information is conceived as a complex, dynamic process that is contradictory and developing and produces results. Information is seen as something that is part of the material world and can be grasped, described, and analyzed by humans in academic work.

- Ontology - Materialism: To make a materialistic analysis of information means to see information neither as purely subjective, nor as purely objective, but as an attribute of matter. It requires a materialistic monist position that sees information as matter in movement, a productive, contradictory, dynamic relationship between material systems that has development potentials so that higherorder qualities that sublate (Aufhebung) the underlying systems in a Hegelian sense can emerge. Information is based on a subject-object-dialectic. That information is contradictory means that in society it is embedded into the antagonisms of capitalism. Information therefore reflects societal problems and potential solutions to these problems. The analysis of information needs to be related to the broader societal context. A critical information theory is negative in so far as it relates information to societal problems and what society has failed to become and to tendencies that question and contradict the dominant and dominative mode of operation and hence have the potential to become positive 
forces of societal change towards the better. It looks for ways of how information can support practical forces and struggles that aim at transcending capitalism and repression as a whole. Based on the insight that the basic resources are highly unequally divided in contemporary society, to construct a critical information theory also means to show how information is related to questions concerning ownership, private property, resource distribution, social struggles, power, resource control, exploitation, and domination. In such an endeavour a reactualized notion of class is of central importance (cf. Fuchs, 2008, chapter 7.3).

- Axiology - Negating the Negative: A critical information theory shows how the two competing forces of competition and cooperation (or other contradictory pairs of the negative and the positive) shape information and result in class formation and produce potentials for the dissolution of exploitation and oppression. It is based on the judgement that co-operation is more desirable than competition, which is just another expression for saying that structures of exploitation and oppression need to be questioned, criticized and sublated.

As there are numerous information phenomena, one can distinguish numerous sub-domains and sub-theories of critical information theory. If we conceive the Internet as a techno-social system that makes use of digital networks to enable threefold information processes of cognition, communication, and co-operation (Hofkirchner, 2002; Fuchs, 2008), then critical Internet theory can be conceived as a subdomain of critical information theory (Fuchs, 2009). Critical Internet theory can be conceived as identifying and analyzing antagonisms in the relationship of Internet and society, it shows how the Internet is shaped and shapes the colliding forces of competition and co-operation, it is oriented on showing how domination and exploitation are structured and structuring the Internet and on how class formation and potential class struggles are technologically mediated, it identifies Internet-supported not-yet realized potentials of societal development and radically questions structures that restrain human and societal potentials for cooperation, self-determination, participation, happiness, and self-management (Fuchs, 2008, 2009).

Why is Marx important for studying information today? Has the author of this paper not learned from history? Is he too young to comprehend the historical errors of Marxism? Why should we return to Marx and rethink and reconsider Marxian categories? Is there anything left of Marxism after the fall of the Soviet Union? Has this fall not invalidated and falsified Marxian thinking? Has it not been shown by history that there are no alternatives to capitalism, that it simply is the more powerful system, that is here to stay, and that it poses an end of history? Has Marxian critique and class analysis not been invalidated by postmodern criticism?

The interesting thing about Marx is that he keeps coming back at moments, at which people least expect it, in the form of various Marxisms that keep haunting capitalism like ghosts, as Jacques Derrida (1994) has stressed. It is paradoxical that almost 20 years after the end of the Soviet Union, capitalism seems to have falsified itself because its neoliberal mode of development has intensified global problems, caused severe poverty and a rise of unequal income distribution, and as a result has brought a return of the economic and with it a reactualization of the Marxian critique of capitalism. Michael Burawoy and Erik Olin Wright (2002, p. 460) argue in this context that it is despite "renewed attempts to bury Marxism" important to "build Marxism", which would involve seeing that "class continues to be at the core of the dynamics and reproduction of capitalism". Although a persistent refrain is "Marx is dead, long live capitalism", Marx is coming back again. "At a time when a new world disorder is attempting to install its neo-capitalism and neo-liberalism, no disavowal has managed to rid itself of all of Marx's ghosts" (Derrida, 1994, p. 37). "True ideas are eternal, they are indestructible, they always return every time they are proclaimed dead" (Žižek, 2008, p. 4). This return certainly needs to rid itself of its historical errors that should not be repeated. But these errors are 
not immanent in Marxian works (Fuchs, 2008), rather only in specific Marxist interpretations. These circumstances enable us to rediscover Marx as theorist of radical egalitarianism and "co-operative selfregulation" (Burawoy, 2000, p. 172).

The relevance of Marx today can be observed and has already been reflected in a number of ways:

- The globalization of capitalism that is seen as important characteristic of contemporary society by many social theorists is an important aspect of the works of Marx and Engels (e.g. Callinicos, 2003). Connected to this topic is also the Marxian theme of international solidarity as form of resistance that seems to be practiced today by the altermondialiste movement.

- The importance of technology, knowledge, and media in contemporary society was anticipated by the Marxian focus on machinery, means of communication, and the general intellect (e.g. Dyer-Witheford, 1999; Hardt \& Negri, 2005; Fuchs, 2008; McChesney, 2007).

- The immizerization caused by neoliberal capitalism suggests a renewed interest in the Marxian category of class (e.g. Harvey, 2005).

- The global war against terror after 9/11 and its violent and repressive results like human casualties and intensified surveillance suggest a renewed interest in Marxian theories of imperialism (e.g. Hardt \& Negri, 2000; Harvey, 2003; Wood, 2003).

- The ecological crisis reactualizes a theme that runs throughout Marxian works: that there is an antagonism between modern industrialism and nature that results in ecological destruction (e.g. Fuchs, 2006; O'Connor, 1998).

- The economic crisis that has hit capitalist economies worldwide in 2008 shows that Marx's crisis theory that argues that crisis is an immanent feature of capitalism is still very topical. So for example Time Magazine put Marx on its cover and asked about the world economy: "What would Marx think?" (Time, February 2, 2009).
As a result, there has been a "renaissance of Marxist political economy" (Callinicos, 2007 , p. 342), with a respectable interest in Marxian or Marxian-inspired thinkers like Giovanni Arrighi, Jacques Bidet, Nick DyerWitheford, Michael Hardt, David Harvey, Robert McChesney, Antonio Negri, or Slavoj Žižek.

Žižek (2008) has recently argued that the antagonisms of contemporary capitalism in the context of the ecological crisis, intellectual property, biogenetics, new forms of apartheid and slums show that we still need the Marxian notion of class and "a proletarian position, the position of the 'part of no-part'" (Žižek. 2008, p. 428). This would be the only way for breaking the "sound barrier" that presents global capitalism as fate without alternatives (p. 459). His suggestion is to renew Marxism and to defend its lost causes in order to "render problematic the all-too-easy liberaldemocratic alternative" (p. 6) that is posed by the new forms of a soft capitalism that promises and in its rhetoric makes use of ideals like participation, self-organization, and co-operation without realizing them.

The core of the relevance of Marx today is normative: the radical critique of capitalism and the envisioning of real alternatives. "Building Marxism as an intellectual project (...) is deeply connected with the political project of challenging capitalism as a social order" (Burawoy \& Wright, 2002, p. 461). That there is a capitalist world economy out of control, in which many are worse off than before, suggests "an opening for Marxism - a renewed critique of capitalism and its protective superstructures" (Burawoy, 2000, p. 152).

We can observe today "stark injustice reflected in the horrifying inequalities in lifechances" (Callinicos, 2006, p. 251). "Doesn't this demand from us a certain kind of partiality? In this riven world, isn't the appropriate standpoint to take that of the victims of injustice, those excluded and denied access to the resources to which they are entitled?" (Callinicos, 2006, pp. 251-252). "There have rarely been times when the intellectual resources of critical social theory were more needed" (Callinicos, 2007, p. 352). These are the reasons why Marxian theory 
and analysis are needed today. This applies for academia in general and in our case specifically for critical media and communication studies. The discovery of Marxian theory could allow a radical emphasis in the contemporary theory and critique of phenomena like global communication, knowledge labour, media and globalization, media and social struggles, media capital accumulation, media monopolies and media capital concentration, the dialectics of information, or media and war.

\section{The problem of immanence and transcendence in critical (information) theory}

Marcuse (1937b) explains that critical theory differs from traditional theory because it is oriented on material changes of society that produce reason and happiness for all. Traditional theory would be idealistic and individualistic because it would conceive freedom and reason as a state of mind, not as a material state of society. Based on its materialism, critical theory would be oriented on social struggles of subordinated groups. Marcuse sets out that critical theory is objective and normative in the sense that it opposes the subordination of humans under the economy (exploitation of labour) and demands a new, different totality. The common element of idealist philosophy and critical theory would be that they both negate capitalism, the first by the notion of the free thinking individual that is more than an economic subject, the second by the interpretation of freedom as a general state of society that humans have to struggle for. Horkheimer (1937/1970) argues that traditional thinking is oriented on instrumental reason. It would be an analysis of that which is positively given and would affirm domination through its ideal of ethical neutrality. Critical Theory in contrast would reflect the difference between possibility and existence.

Marxian critique from its beginning was a critique of religion, the critique of capitalism can be considered as an enhancement of the critique of religion that shows the historical and ideological character of capitalism. As Marxian critique analyzes the inherent contradictions of capitalism that produce crises, it shows that capitalism through the antagonism between productive forces and relations of production contains and develops its own negativity. Such a method of critique is immanent critique: it starts from the conditions of capitalism without appealing to transhistorical values or religious sense. However, such an interpretation of Marxian critique as pure immanent critique has historically resulted in deterministic interpretations of history that have been historically falsified. Therefore it has been stressed that Marxian critique also contains transcendental elements (e.g. Lukes. 1985; Sayers, 1997) - the vision of a co-operative society as the best form of human existence. Marxian critique is transcendental not in an idealistic or religious sense, the transcendence that it imagines is a not-yet existent society that is anticipated by the existence of the proletariat and that has its material preconditions in capitalist itself. It is an immanent transcendence coming from the inside of society itself. Marxian critique can in this sense be best interpreted as dialectic of immanence and transcendence. Since the late 1970s Marxian critique and transcendentals in general have come under heavy attack by postmodern thought, which argued that all notions of truth and essence are totalitarian. Marxian critique was increasingly superseded by strictly immanent critiques (cf. e.g. Deleuze, 2001; Foucault, 1977; Lyotard, 1979) oriented on identity politics and local reforms. Postmodernism has in recent years been challenged by various approaches that show a new focus on transcendental notions of Marxist critique: transfactuality by Roy Bhaskar (1993), transcritique by Kojin Karatani (2003), or the transempirical as totality of the world that is given reason for by dialectical philosophy in the works of Hans Heinz Holz (2005).

Fotini Vaki (2005) has argued that transcendental elements in Marxist thinking, especially Habermas' notion of communicative rationality in dominationless discourse, are unhistorical, idealistic, fetishistic, and based on the notion of an essential and pure identity. An alternative would be a complete immanent critical theory. $\mathrm{He}$ sees such an immanence realized in 
Adorno's Negative Dialectics, which is focusing on internal contradictions and negations of capitalism and does not assume a transcendental outside. However, it can be argued that in Adorno's theory, non-identity realized in the position of the critical theorist who maintains a position outside of instrumental reason and autonomous art in his Aesthetic Theory constitute transcendentals because they are considered as resisting moments that question the repressive totality. All Marxist thinking to a certain extent contains transcendental elements.

Some observers have argued that Horkheimer's and Adorno's critical theory was an immanent critique (Calhoun, 1995, p. 23; Honneth, 2007, pp. 61, 64). But for both Max Horkheimer and Theodor Adorno transcendental elements of Critical Theory are important. So e.g. Horkheimer speaks of the need for a society without injustice or conditions without exploitation and oppression (Horkheimer, 1937/1970, pp. 238, 257). In the chapter on The Concept of Enlightenment in the Dialectic of Enlightenment, Horkheimer argues that transcendentalism is important and is destroyed by positivist thinking that is based on pure immanence: "The pure immanence of positivism, its ultimate product, is nothing other than a form of universal taboo. Nothing is allowed to remain outside, since the mere idea of the 'outside' is the real source of fear. (...). Enlightened thinking has an answer for this, too: finally, the transcendental subject of knowledge, as the last reminder of subjectivity, is itself seemingly abolished and replaced by the operations of the automatic mechanisms of order, which therefore run all the more smoothly" (Horkheimer/Adorno, 1944/2002, pp. 11, 23). These passages show that Horkheimer considered transcendentalism very important and as a form of non-identity that needs to be upheld against positivism.

Immanence for Horkheimer and Adorno was not a positive feature of critical theory, but was seen as the feature in society that critical theory questions.

Even those who argue that capitalism through its inner contradictions produces crises and hence its own demise, which will result in communism, have the notion of a notyet existing outside. The question is only to which degree this transcendentalism is stressed and how it is related to agency or potential agency. Here, various traditions of Marxian thinking differ. Some are more actiontheoretic, some more structuralistic, some rather dialectically balanced. All of them have in common that the transcendental elements are not posited outside of society, but are anchored in the inner contradictions of capitalism, such as the antagonism between the productive forces and the relations of production. Hence Marxist transcendentalism is materialist and based on a societal immanence, it is an immanent transcendentalism or transcendental immanence. Structural Marxists tend to argue that the future of society is mainly shaped by the internal contradictions of capitalism, which are seen as constituting a potential outside and/or a repressive ideological affirmation of the status quo. Humanist Marxists tend to argue that the potential outside is constituted mainly through class struggles. A third position tries to combine both structural and agency-oriented immanent transcendentalism. Next, I will try to show that the two main definitions of critique besides Marxist critique -positivistic critique and postmodern critique- are both based on a immanence without transcendence.

\subsection{The positivistic notion of critique}

The difference between traditional theory and critical theory and between immanence and immanent transcendence was also the implicit categorical difference in the positivism debate in German sociology in 1961. Popper's (1962) understanding of critique is purely immanent in the sense that it is focusing on epistemological/methodological procedures without taking into account how academia is shaped by worldviews, political goals, and the world outside of academia. Popper can be considered as a representative of traditional theory because he sees critique and truth as individual and subjective concepts. These are idealistic notions for him. Adorno's notions are materialistic because he sees them as oriented on society as totality and its material conditions. 
There are standardized psychological tests, such as the California Critical Thinking Disposition Inventory (CCTDI) or the WatsonGlaser Critical Thinking Appraisal (WGCTA), available that aim at measuring critical thinking. However, most of these tests are based on a purely positivistic notion of critique. Aspects of questioning domination, as typical for Marxian thinking, are missing.

The authors of the CCTDI test define critical thinking based on the results of a Delphi project that was conducted by the American Philosophical Association in 1990. The qualities listed all fall within the cognitive and communicative dimensions of the central characteristics of positivistic thinking (cf. Facione, et al., 1995). The CCTDI is made up of 75 6-point likert scale items and seven scales (cf. Facione, et al., 1995; Giancarlo \& Facione, 2001): 1. Truthseeking (desire for best knowledge, inclination to ask challenging questions), 2. Openmindedness (tolerance for new ideas and divergent views), 3. Analyticity (anticipating difficulties, alertness for the need to intervene and solving problems), 4 . Systematicity (inclination to be organized), 5 . Critical thinking self-confidence (trust in one's own reasoning), 6. Inquisitiveness (intellectual curiosity for learning new things), 7. Maturity of judgment (judiciousness in complex decision-making). Most of these seven scales can be mapped to three central elements of positivistic thinking: assessment and opinion formation $(4,5,6)$, asking questions (1), constructive change $(3,7)$. The second scale reflects the postmodern quality of plurality. Elements of Marxian critique are missing. Another limit of this test is that it is purely quantitative and therefore cannot take into account qualitative arguments and opinions that can only be observed if respondents are asked to write answers to asked questions.

There are also more qualitatively oriented tests of critical thinking, such as the EnnisWeir Critical Thinking Essay Test (Ennis \& Weir, 1985). The respondents are asked to read a letter to the editor of a newspaper and to write a response paragraph for each paragraph of the letter. The tested characteristics of critical thinking are again either positivistic (such as "stating one's point", "seeing the reasons and assumptions", "getting the point", "offering good reasons") or postmodern ("seeing other possibilities, including other possible explanations") (Ennis/Weir 1985: 1).

Burbules and Berk (1999, p. 46f) point out the difference between Critical Thinking approaches and Marxian-inspired Critical Pedagogy in education: "The Critical Thinking tradition concerns itself primarily with criteria of epistemic adequacy. (...) The prime tools of Critical Thinking are the skills of formal and informal logic, conceptual analysis, and epistemology. (...) The primary preoccupation of Critical Pedagogy is with social injustice and how to transform inequitable, undemocratic or oppressive institutions and social relations".

Henry Giroux has characterized the Critical Thinking approach as positivistic and ideological: "The most powerful, yet limited, definition of critical thinking comes out of the positivist tradition in the applied sciences and suffers from what I call the Internal Consistency position. According to the adherents of the Internal Consistency position, critical thinking refers primarily to teaching students how to analyze and develop reading and writing assignments from the perspective of formal, logical patterns of consistency (...) While all of the learning skills are important, their limitations as a whole lie in what is excluded, and it is with respect to what is missing that the ideology of such an approach is revealed" (Giroux, 1994, pp. 200f).

\subsection{The postmodern notion of critique}

The main postmodern critique of notions such as essence, ground, foundation, truth, unity, or universals is the argument that such categories can be used for legitimating grand narratives of domination. Especially Soviet Marxism would have used such a strategy. Therefore it would be better to assume that all social structures are pure social constructions, that history is fully relative and open to chance, and that there are no forms of unity and universal commonalities of humans or society. Judith Butler in this context argues against dialectical thinking that dialectical causation introduces a primacy of certain categories that she sees as "imperializing gesture of dialectical appropriation" (Butler, 
1990, p. 19). "Dialectical appropriation and suppression of the Other is one tactic among many, deployed centrally but not exclusively in the service of expanding and rationalizing the masculinist domain" (Butler, 1990, p. 19).

The poststructuralist critique of universal essence has most clearly been formulated by Foucault and goes back to his interpretation of Nietzsche. Rainer Winter (2007) argues that the validity of critical theory depends on its recipients and whether they are strengthened by it in its action capacities or not. Not only Habermas's theory, but also Foucault's genealogy would be a continuation of critical theory. Foucault's focus on micro-practices and the micro-structures of power is for Winter a foundation for the claim that in a society where classical critical theory has lost its transcendental revolutionary subjects, "cultural studies accept the inheritance of critical theory" (Winter, 2007, p. 32). For Foucault, the method of genealogy is opposed to the search for origins, things would "have no essence or (...) their essence was fabricated in a piecemeal fashion from alien forms" (Foucault, 1977, p. 142). History would not have the inherent potential for freedom and reason: "Humanity doesn't gradually progress from combat to combat until it arrives at universal reciprocity, where the rule of law finally replaces warfare; humanity installs each of its violences in a system of rules and thus proceeds from domination to domination" (p. 151). Genealogy "refuses the certainty of absolutes" (p. 152), history would be negative, dominative, chance, conflict, lost, and an error. Genealogy would be directed against the notion of history as: 1 . Reminiscence or recognition; 2. Continuity or representative of a tradition; 3 . Truth and knowledge (p. 160). Things should be defined "without reference to the ground, the foundation of things, but by relating them to the body of rules that enable them to form as objects of a discourse and thus constitute the conditions of their historical appearance" (Foucault, 2002, p. 53).

Rorty formulated similar ideas. "So we have come to distrust the people who tell us that 'you cannot change human nature' - a slogan that was employed against the education of women, interracial marriage, and gay liberation" (Rorty, 1998).
It is certainly important and true that the notion of essence has been used as an ideology that legitimates oppression. So e.g. Hitler argued that the inner essence of Jews is parasitism. He wrote in Mein Kampf that the Jew in "order to carry on his existence as a parasite on other peoples, he is forced to deny his inner nature" (Hitler, 1925, p. 335). Herbert Marcuse (1941) has argued that the Nazi notion of essence is based on particularism and is opposed to the Hegelian and Marxian notion of essence, which assumes the existence of universal qualities of humans and society. For Hegel, essence is not a particularistic, but a universalistic concept. He argues: "The Absolute is the Essence" (Hegel, 1830, §112). Essence is ground of existence. The ground is the unity of identity and difference (...) It is essence put explicitly as a totality" (Hegel, 1830, §121). In Marx's philosophical writings, Hegelian essence is interpreted as sociality and cooperation. "The individual is the social being" (MEW 40, p. 538). The implication of this assumption is that co-operation is something that all humans share, that capitalism alienates the potentials for capitalism, and that societal conditions should be created that allow all humans to participate and to have equally realized rights and to live in equity. It is this stress on universal equity that led to the Nazis' hostility towards Hegel and Marx. So e.g. in the main work by Alfred Rosenberg (1930), the Nazis' primary ideologist, Hegel is opposed because for him the state was a universal concept. Rosenberg argues that Hegel's and Marx's writings are foreign to the notion of blood ("blutfremd") (Rosenberg, $1930,525)$, whereas Nietzsche is celebrated as someone who destroyed all values and stood for the breeding of a higher race ("rassische Hochzucht") (Rosenberg, 1930, p. 525). Herbert Marcuse summarizes the Nazi's opposition towards Hegel's universalism: "The state as reason - that is, as a rational whole, governed by universally valid laws, calculable and lucid in its operation, professing to protect the essential interest of every individual without discrimination - this form of state is

\footnotetext{
4 "Er muß, um sein Dasein als Völkerparasit führen zu können, zur Verleugnung seiner inneren Wesensart greifen".
} 
precisely what National Socialism cannot tolerate" (Marcuse, 1941, p. 413).

The postmodernist enmity towards universalism and essence makes it impossible to envision a state of society, in which there is universal wealth and well-being for all, and impossible to assess such conditions as normatively desirable. Postmodernism does not have a political vision. Butler (1990) and Rorty (1998) argue that an emerging unity is acceptable if it is not apriori envisioned, but emerges spontaneously. Foucault (1977) argues that human history is a sequence of domination, he sees no possibility for the realization of universal reason and happiness. That something emerges spontaneously from below does not guarantee that it benefits all. Butler's and Rorty's postmodern antiessentialism and anti-foundationalism is relativistic, it equalizes all societal conditions, e.g. fascism and participatory democracy. In my opinion, it therefore trivializes the bestiality of fascism because it does not provide categories that allow normative judgement of such conditions. Foucault's anti-essentialism and anti-foundationalism results in a negative concept of history, although he opposes universalism and essentialism, he essentializes human history as necessary dominative. Foucault's method of genealogy does not know the possibility of human and societal betterment, wealth and equity for all.

The alternative for us is to assume, as Herbert Marcuse did, that there are universal human characteristics such as sociality, cooperation, or the desire for wealth, happiness, freedom, reason, that conditions should be created that allow the universal realization of these qualities, that societies that do not guarantee the realization of these human potentials are false societies, and that consciousness that wants to perpetuate such false societal conditions is false consciousness. Such a form of universalism is not totalitarian, but should be read as a form of humanism that struggles for universal equity. Only the assumption that there is something positive that all humans have in common allows the envisioning of a state where all humans are guaranteed equal fundamental rights. Such essential conditions are not given and envisioned automatically, they have historical character and under given economic, political, cultural, and technological conditions they can be reached to a certain degree. Humans have the ability to struggle and to act consciously in transformative ways. Therefore each societal epoch is shaped by the question if humans will or will not act to create and realize the epoch's inherent and dynamically developing potentials or not. They shape and potentially enhance the space of possibilities and at the same time act or do not act to realize these created possibilities. Human essentials are substantial, if they are achieved or not and to which extent they can be realized and how they develop is completely historical, i.e. based on human agency. In Marx's works "the negativity of reality becomes a historical condition which cannot be hypostatized as a metaphysical state of affairs. (...) The given state of affairs is negative and can be rendered positive only by liberating the possibilities immanent in it. (...) Truth, in short, is neither a realm apart from historical reality, nor a region of eternally valid ideas. (...) Not the slightest natural necessity or automatic inevitability guarantees the transition from capitalism to socialism. (...) The revolution requires the maturity of many forces, but the greatest among them is the subjective force, namely, the revolutionary class itself. The realization of freedom and reason requires the free rationality of those who achieve it. Marxian theory is, then, incompatible with fatalistic determinism" (Marcuse, 1941, pp. 314f, 318f).

Marcuse anticipated the critique of postmodern relativism when he argued in 1936 for a Marxist notion of essence: "A theory that wants to eradicate from science the concept of essence succumbs to helpless relativism, thus promoting the very powers whose reactionary thought it wants to combat" (Marcuse, 1968, p. 45). It makes practical political sense to argue that there is a truth immanent in society that is not automatically realized and that this truth is given in the need and possibility for a good life for all. What one can take as an important insight from postmodern theory is that oppression takes on different forms and contexts and that oppressed individuals and groups frequently stand in contradictory relations to each other. Bringing both arguments together allows to assume that truth is subdivided into partial 
truths that are interconnected, oppressed groups and individuals share common interests because they are all confronted by the same global system of oppression, at the same time they also have differing subinterests because oppression is contextualized in many forms. What is needed is a differentiated unity, a form of politics that is based on unity in diversity.

There is a number of typologies of critical theories that consider postmodernism as always critical and Marxian theory only as one among several types of critical theories. Lois Tyson conceives critical theory as a method of analyzing texts: "when we interpret a literary text, we are doing literary criticism; when we examine the criteria upon our interpretation rests, we are doing critical theory" (Tyson 2006: 6). He distinguishes between 11 types of critical theory that can be applied to the deconstruction of texts: psychoanalytic criticism, Marxist criticism, feminist criticism, new criticism, reader-response criticism, structuralist criticism, deconstructive criticism, new historical and cultural criticism; lesbian, gay and queer criticism; African-American criticism, and postcolonial criticism (Tyson, 2006). Douglas Tallack has established a similar typology of different forms of critical theory. For him critical theory is characterised by deconstructive self-reflexivity, immanent critique, and the examination of truth as the primary focus for analysis (Tallack, 1995, p. 3). Tallack differentiates between five forms of critical theory: Marxism, Structuralism and Post-Structuralism, Psychoanalytic theory, feminism, post-foundational ethics and politics. David Hoy (Hoy, 2004) criticizes Frankfurt school critical theory as a totalizing meta-narrative and suggests that postmodernism should be considered as a new form of critical theory. He speaks in this context of critical pluralism (Hoy \& McCarthy, 1994, p. 200) and of post-critique (Hoy 2004). Post-critique would be characterized by permanent self-critique, i.e. the questioning of its own foundations. Hoy (2004) discusses Nietzsche, Deleuze, Foucault, Bourdieu, Levinas, Derrida, Laclau, Mouffe, Žižek. Postcritique is a synthesis of Derrida's ethics and Foucault's politics that Hoy also terms "deconstructive genealogy".
Tyson's and Tallack's typologies are informed by postmodern thinking, they argue for a plurality of different notions of critique. The main focus lies on the examination and deconstruction of truth. According to this point of view, texts, and the truths that they embody, can be analyzed from different perspectives like feminism, structuralism, queer criticism, postcolonial-criticism, etc. This shift from power and domination to truth as the central category of critique means a major change in the form of critical analysis. Steven Best and Douglas Kellner have argued in this context that such endeavours HAS lead to relativistic approaches: "Postmodern theories can be used to attack or defend modernity, to reconstruct radical politics or to declare their impossibility, to enhance Marxian theory or to denounce it, to bolster feminist critiques or to undermine them." (Best \& Kellner, 1991, p. 356). Best and Kellner point out that postmodern theories limit themselves to the observation of different forms of oppression without placing them into a societal context: "Postmodern theory splits capitalist society into separate and unmediated realms, analyzing culture in isolation from the economy, or politics apart from the conjuncture of business and government" (Best \& Kellner, 1991, p. 289). As we live in a capitalist society, considering the societal context always means looking at the economic dimension of societal problems. This does not mean a reduction to the economic realm, but the awareness that different forms of oppression, besides of having distinctive features, cannot be considered as unmediated and are linked by the societal context in which they take place. Thus postmodern approaches that do not take into consideration the societal context, and therefore the economic dimension of certain societal problems, cannot be understood as critical theories. This means that I only consider postmodern approaches as critical if they connect their analyses to aspects of class and economic exploitation. Not all postmodern approaches are critical in this sense of the term, only some or even few of them. Especially those that give a specific attention to class and Marxian theory should be considered as critical. For example Michael Hames-García argues in this context 
that most of contemporary queer theory is uncritical because it has "consistently resisted the consequences of a truly substantive, thorough and ongoing engagement with theories that are more centrally concentrated with race and class" (Hames-García 2001: 218). "I therefore suggest that another task for a critical queer theory should be a reintroduction of materialist questions of class and capitalism. (...) The goal of a critical theory of gay and lesbian identity (...) should be to elucidate those connections that exist between capitalism and the regulation of sexuality" (Hames-García, 2001, p. 216).

Positivism and postmodernism are both based on the figure of immanence without transcendentals. There is also the figure of transcendentals without immanences, as for example in all religious and esoteric knowledge that claims certain existences that are not grounded in the immanence of matter. Another example for transcendentals without immanence are political utopias that promise types of society that are not materially feasible based on the available structures, the state of development of the productive forces, the political system, and the given cultural system. An example are the utopian socialists that Marx and Engels criticized in the Communist Manifesto (MEW 4, pp. 482-493). A viable alternative to immanence without transcendence and transcendence without immanence is a critical theory that is based on the dialectic of immanence and transcendence, i.e. immanent transcendence.

\subsection{Critical theory as immanent transcendence}

I favour a normative Marxian definition of critique, decline the positivistic definition of critique as ideological, and see postmodern thought only as critical if it acknowledges the central importance of class analysis. It should have become clear that there are three competing major understandings and definitions of critique at work today:

\section{Representatives of a positivistic notion of} critique argue that it is important that each individual engages in discourse, assesses arguments, forms his/her own opinion, and articulates her/his views. It would be wrong and even dangerous for democracy if individuals passively accept opinions. The positions are strictly individualistic, as can be seen in formulations like: "Critique means to engage in a debate, to assess the arguments, and to form ones own opinion".

2. Postmodern critique is always oriented on challenging hierarchies, it does not accept the notions of truth and objectivity, and argues for liberal pluralism. E.g. it typically argues: "There is no ultimate standard of judging what is true because such standards are themselves socially constructed and shaped by power relations. Therefore there is no objective standard in society, only a plurality of different meanings and identities. It is therefore important to deconstruct truth claims, to accept other opinions as possible and legitimate ones and formulate ones own as equally reasonable".

3. Marxist critique is a specific form of objective knowledge that is achieved by being partial and not denying, but engaging in and showing the interconnection of academia and politics. It takes the standpoints of the oppressed. It is characterized by normative, objective, and political standpoints of the speakers, it speaks for whole groups, not just for individuals. It argues not just that one should form certain opinions, but that there are true and false opinions corresponding to true and false states of society. Typically, terms like domination, exploitation, class, power, or capitalism are used as negative terms. An ideal type of such a position is the following one: "Critique means to see all forms of domination and exploitation as repressive and to struggle against these conditions. It points towards a state of nondomination, a classless society". 
Table 4: A typology of qualities of three notions of critique

\begin{tabular}{llll}
\hline & \multicolumn{1}{c}{ Individual opinions } & \multicolumn{1}{c}{ Interaction } & Transformative action \\
\hline Positivism & $\begin{array}{l}\text { Assessment and opinion } \\
\text { formation }\end{array}$ & Asking questions & Constructive change \\
\hline $\begin{array}{l}\text { Postmoder- } \\
\text { nism }\end{array}$ & $\begin{array}{l}\text { Accepting a plurality of } \\
\text { views and knowledge as } \\
\text { legitimate }\end{array}$ & $\begin{array}{l}\text { Questioning dominant } \\
\text { views }\end{array}$ & $\begin{array}{l}\text { Local reform and identity } \\
\text { politics }\end{array}$ \\
\hline Marxism & $\begin{array}{l}\text { Partisanship for the } \\
\text { oppressed, dominated, } \\
\text { and exploited }\end{array}$ & Anti-capitalist praxis & Revolution \\
\hline
\end{tabular}

Individual opinions (cognition), interaction (communication), and transformative action (co-operation) can be considered as three informational levels of defining critique (table 4). This understanding is based on the notion of information as threefold nested process of cognition, communication, and co-operation (Hofkirchner, 2002; Fuchs, 2008). The three aspects of information form a triad: First there is an individual aspect describing which opinions are formed by a person, then there is an interaction, the actor communicates with others concerning a specific question, third there is action that aims at transforming social reality. Such transformations are again the foundation of the formation and reproduction of opinions, so that a dynamic process of cognition, communication, and co-operation emerges. This relationship can be interpreted as a dialectical Hegelian triad of identity (being-in-itself), being-for-another (negation), and being-in-and-for-itself (negation of the negation). Also each of the three dimensions (individual, interaction, transformation) can be read as a dialectical triad, in which the Marxist position sublates the positivistic and the postmodern standpoints.

Positivism is very general. It argues that any sort of opinion, questioning, and change is desirable. Postmodernism is more specific, it argues for a plurality of opinions and identities. Marxism sublates this contradiction between the general and the specific by arguing for a concrete unity (specific) that is considered as a universal norm (general). It not just argues for any opinion, questioning asking, or change, and not for a plurality, but for a unity in plurality of all oppressed groups and individuals that is partisan, anti-capitalist, non-dominative, and revolutionary. Marxist critique is also seen as integrative form of critique by Wolfgang Bonß (2003), who considers it as the unity of empirical (positivistic), immanent, and normative critique, and by Axel Honneth (2007), who sees it as the unity of normative (constructive), immanent (reconstructive) and genealogical critique (deconstruction of truths).

Here is a description of the categories employed in the typology:

- Positivistic individual opinion: This aspect is applicable if an actor describes critique as the individual evaluation of other statements in order to form a personal view and position himself/herself.

- Positivistic interaction: This dimension is given if critique is described as asking questions to others in order to clarify the consistency of statements.

- Positivistic transformative action: This quality is positively given if it is suggested in a unity of analysis that critique must always be positive, i.e. make suggestions how to improve a situation immanently. There is an orientation on dialogue, improvements, and finding better solutions.

- Postmodern individual opinion: Plurality of knowledge and opinions is one central aspect of postmodernist thought. This attitude is held if it is stressed that it is important that different opinions can be 
voiced and should be recognized as legitimate.

- Postmodern interaction: This notion is applicable if critique is described as challenging authorities, absolute knowledge, universalism, the notion of truth, or dominant opinions.

- Postmodern transformative action: Desirable change in postmodernist thought is conceived as the acknowledgement or struggle for acknowledgement of the identity of certain groups or as local reform politics. It is a politics of difference and plurality.

- Marxist individual opinion: This quality can be found if a normative notion of critique that stresses partisanship for oppressed, discriminated, exploited, or dominated groups or individuals is present.

- Marxist interaction: This form of interaction is present if questioning and practical negation in terms of class interests, injustice, and fair socio-economic distribution is present in a text.

- Marxist transformative action: Marxist views hold that the totality of contemporary society needs to be fundamentally transformed (sublated) in class struggles in order to overcome societal problems and establish a just, fair, co-operative, participatory society.

In their debate on Recognition or Redistribution? (Fraser \& Honneth, 2003), critical theorists Nancy Fraser and Axel Honneth both argue for the philosophical position of immanent transcendence. Fraser characterizes this position as seeking for "a foothold in the social world that simultaneously points beyond it" (Fraser \& Honneth, 2003, p. 202). Honneth speaks of the dialectic of immanence and transcendence (Fraser \& Honneth, 2003, p. 238). Honneth (2007, pp. 57-69) distinguishes between a constructive, transcendental critique, a reconstructive, immanent critique, and a Foucaultian genealogical critique. Critical theory would combine all three forms. In the debate with Fraser, he characterizes this combination as immanent transcendence. Transcendence "must be attached to a form of practice or experience which is on the one hand indispensable for social reproduction, and on the other hand - owing to its normative surplus - points beyond all given form of social organization. (...) 'transcendence' should be a property of 'immanence' itself, so that the facticity of social relations always contains a dimension of transcending claims" (Fraser \& Honneth, 2003, p. 244). The difference is that Fraser sees the immanent element of contemporary society that can transcend it in social movements that engage in political struggles (Fraser \& Honneth, 2003, p. 205), whereas Honneth is very critical of new social movements (Fraser \& Honneth, 2003, pp. 114-125), considers them as rather affirmative, and sees immanent transcendence in an objective morality that should be legally implemented in the form of laws.

For Fraser, the orientation towards social movements is a central aspect of critical theory: "A critical social theory frames its research program and its conceptual framework with an eye to the aims and activities of those oppositional social movements with which it has a partisan though not uncritical identification. The questions it asks and the models it designs are informed by that identification and interest. Thus, for example, if struggles contesting the subordination of women figured among the most significant of a given age, then a critical social theory for that time would aim, among other things, to shed light on the character and bases of such subordination. It would employ categories and explanatory models which revealed rather than occluded relations of male dominance and female subordination. And it would demystify as ideological rival approaches which obfuscated or rationalized those relations" (Fraser, 1985, p. 97). But what if the most significant and only social movement of a time is fascism and all antifascist movements and forces are contained or have been killed. Should critical theory then be aligned with fascism just because it is a political movement? Certainly not. The example shows that critical theory needs to be able to make political judgments, even if there are at certain moments no movements that it can align itself with. For Fraser, specifically the feminist movement is of importance for 
critical theory. Therefore she criticizes Habermas and argued that his theory of communicative action is gender-blind. "The struggles and wishes of contemporary women are not adequately clarified by a theory which draws the basic battle line between system and lifeworld institutions" (Fraser, 1985, p. 130). Honneth argues that Fraser's strong focus on gender and sexuality as examples creates the image that "capitalist societies are marked primarily by social conflicts driven by demands for cultural recognition" (Fraser \& Honneth, 2003, p. 120).

The problem for Fraser is that there can be situations in society, where political protest is forestalled, which nonetheless require essential criteria for judging what is politically right and wrong. Fraser's approach is nonfoundational and deontological. Her neglect of assuming a stable ethical reference point poses the danger of relativism, especially in situations where political opposition is forestalled. Her reference point is purely dynamic and historical. The problem for Honneth is his pure reliance on law, which will fail in situations where laws are highly unjust (as in fascism), which requires social movements to protest and overthrow institutionalized injustice. The resolution of this dilemma is to argue for essential norms of judgment that can guide thinking and action under all societal circumstances and to see it as a further task of critical social theory to try to find ways to politically realize these norms by creating a theory/praxis-connection that involves a combined effort of civil society and political parties.

That morals are part of all institutions is not enough an argument for saying that they are primary in society. For Honneth, consciousness determines being. Alex Demirovic (2003a, p. 13) criticizes that with Habermas, who is Honneth's most important influence, critical theory has strongly turned from a critique of societal totality into a moral critique. Before one can experience malrecognition subjectively, conditions that have caused the situation of malrecognition must exist and must have been created. Fraser argues that "recognition monism" is blind for phenomena that "cannot be reduced to cultural schemas of evaluation", such as supply and demand of labour, power relations between labour and capital, the outsourcing of labour, etc (Fraser \& Honneth, 2003, p. 215). Therefore there would exist struggles over distribution, which are not struggles over recognition (lbid). Fraser characterizes Honneth's approach as "truncated culturalism" (Fraser \& Honneth, 2003, p. 216).

For Fraser, immanent transcendence is pure struggle, purely political, historical, and relative, for Honneth it is cultural and psychological. He builds on Habermas's shift from the focus on labour to the focus on interaction in such a way that immanent transcendence becomes moralistic, cultural, and symbolic. An alternative strategy is not to assume a political or a psychological reference point for immanent transcendence, but a societal one so that society is considered as providing its own moral values and essence and can, based on historical circumstances, more or less approximate or diverge from the realization of this essence. Such an approach that is crucial for the writings of Marcuse and young-Marx, is both static and dynamic, foundational and historic.

Marx and Engels considered morals as ideologies that try to legitimate religious, economic, and political domination and oppression and serve class interests by postulating the authority of an absolute subject. Marx considered religion and morals as opium of the people and right (the defence of morals in the form of laws by the state) as a mechanism for protecting private property. Marxists like Antonio Gramsci, Theodor W. Adorno, Max Horkheimer, and Louis Althusser have further elaborated this aspect of Marxism as ideology critique. Marx and Engels argue that morals are an expression of coercive societies and that morality will vanish with the disappearance of class antagonisms because there will be no fundamental conflicts of interests that have to be legitimated ideologically. Moral theories would be a consequence of the economic conditions of society and morality class morality. They argue that their approach is not a moralistic, but a scientific one because they identify tendencies of the development of the productive forces that produce the potential for communism as a higher form of existence. The alternative to preaching morality here seems to be the identification of deterministic 
laws of history. Steven Lukes (1985) has pointed out that the writings of Marx and Engels on moral questions are paradox because besides the stress on historical laws instead of morals one can find a lot of moral expressions that condemn capitalism as oppressive, exploitative, alienating, estranging, heteronomous, and present the vision of a better world ("the realm of freedom") that is characterized by wellrounded individuality, pluralistic activities, abundance, the abolition of hard work and wage labour due to technological productivity, the disappearance of the performance principle and exchange, the free production and distribution of goods (“... from each according to his ability, to each according to his needs ..."), and free time for idle and higher activity. The concept of freedom that Marx and Engels put forward questions freedom as the freedom of private property ownership in means of production and understands it instead as freedom from scarcity and domination and as a community of associated individuals that provides wealth, self-ownership, self-realization of human faculties, and self-determination for all. They considered the bourgeois concept of freedom as narrow and as reducing freedom to free trade, free market, free buying, free wage labour, i.e. to the sphere of money that radically constrains the practical alternatives of action. Bourgeois freedom would make the producers free from their product and would hence in fact be a form of unfreedom. In this context the notion of alienation arises and signifies compulsory wage labour, dispossession, and the crippling of human faculties.

Especially Lenin, Trotsky, and Stalin took up Marx's and Engels's concept of morality as class morality and of social development as lawful, pre-determined process. Determinist readings of Marx argue that a better society does not come about because it is ethically justified, but because it is causally produced. Paradoxically this ended up in a new morality that became an ideology that legitimated an oppressive regime (Marcuse, 1958; Fuchs, 2005, pp. 140-150). Stalinism recoded bourgeois values like family, performance, and hard work in order to arrive at an alternative morality that argued that under a
Socialist rule old values serve higher principles. The result was a moral that resembled the Protestant Ethics of capitalism, but was characterized as Socialist Ethics. The results of such thinking were monstrous worldviews and policies, as e.g. formulated in the 1936 Soviet Constitution by Stalin: "In the U.S.S.R. work is a duty and a matter of honor for every able-bodied citizen, in accordance with the principle: 'He who does not work, neither shall he eat'. The principle applied in the U.S.S.R. is that of socialism: 'From each according to his ability, to each according to his work'. (\$12)" The humanism of Marxian thinking got completely lost here. The original Marxian formulation said: "From each according to his ability, to each according to his needs". Soviet Ethics were based on the idea that privations and dictatorship were needed in order to establish a free society and to develop the productive forces. The idea of communism became an ideology and a transcendental absolute idea that legitimated a coercive system that was not all too different from capitalist principles of domination. The idea that history is a lawful process and that hence socialism follows capitalism became an ideology that allowed Stalin to persecute all critics by arguing that the Soviet system in any form is a Socialist society because it is a social formation following capitalism and that any criticism of the system is counterrevolutionary and means critique of Socialism and to suggest a return to capitalism.

The alternative to a determinist interpretation of Marx and Engels is to acknowledge a certain importance of morality in Marxism, expressed by the Marxian categoric imperative, and to understand it as a philosophy of praxis that aims at the sublation of domination and exploitation in the practice of human emancipation and self-organization. For Hegel the essence of things means that they have fundamental characteristics and qualities as such that frequently are different from their appearance. Truth for Hegel is the direct correspondence of essence and existence, only true existence being real and reasonable. In Marxism, especially Herbert Marcuse has taken up Hegel's notion of essence and has stressed that essence is connected to possibilities and that a true society is one that realizes the possibilities 
that are enabled by its structural aspects such as technological forces, economic productivity, political power relations, worldviews, etc (Marcuse, 1964a, 1968; Fuchs, 2005, pp. 20-37). Essence in society is connected with what humans could be (Marcuse 1968). Ernst Bloch (1959) utilizes in this context the ontological category of "not yet" in order to signify concrete potentials that can be realized, but have not yet been realized. Marcuse has given the following definition of the essence of man and society: "Connecting at its roots the problem of essence to social practice restructures the concept of essence in its relation to all other concepts by orienting it toward the essence of man. (...) Here the concept of what could be, of inherent possibilities, acquires a precise meaning. What man can be in a given historical situation is determinable with regard to the following factors: the measure of control of natural and social productive factors, the level of the organization of labor, the development of needs in relation to possibilities for their fulfilment (especially the relation of what is necessary for the reproduction of life to the 'free' needs for gratification and happiness, for the 'good and the beautiful'), the availability, as material to be appropriated, of a wealth of cultural values in all areas of life" (Marcuse, 1937a, p. 71).

For Marcuse, ethics is connected with questions of what can and should be because it can reduce pain, misery, and injustice (Marcuse, 1964a, p. 106) and use existing resources and capacities in ways that satisfy human needs in the best possible way and minimize hard labour (Marcuse, 1964a, p. 112). A false condition of society or a social system would mean that its actuality and its potentiality differ. Marcuse stresses that in capitalism oppressed humans are alienated because they are dispossessed and that alienation means that humans and society are alienated from their essence. The sublation of the alienation of labour and man by establishing a realm of freedom means then the realization of the human and social essence. One can read the works of Marx as a deconstruction of ideology, the identification of potentials that strengthen the realization of human freedom, and the suggestion that humans should act in ways that realize potentials that increase the co-operative character of society. Here both chance and necessity are important: Existing structures, i.e. social relations and forces of production in economy, polity, and culture, determine certain potentials of societal development (necessity), the human being in its social practices realizes potentials by creating actuality (chance). Freedom here is freedom to create novelty that is conditioned (enabled and constrained) by societal reality. Marx's works can be interpreted as an ethics of liberation and co-operation in so far as they suggest that humans should act in ways that bring society closer to the latter's co-operative essence. Marx's stress on socialization (Vergesellschaftung) shows that he saw cooperation as an essential societal phenomenon and considered the realm of freedom as the realization of the co-operative essence of society. This is what Marx means when he e.g. speaks of "the return of man from religion, family, state, etc., to his human, i.e., social, existence" (MEW 40, p. 537), the "complete return of man to himself as a social (i.e., human) being" (MEW 40, p. 536), "the positive transcendence of private property as human self-estrangement, and therefore as the real appropriation of the human essence by and for man" (MEW 40, p. 536). For Marx, co-operation is an objective principle that results in a categorical imperative that in contrast to Kant stresses the need for an integrative democracy: Marx argues that critique ends with the insight that "man is the highest essence for man - hence, with the categoric imperative to overthrow all relations in which man is a debased, enslaved, abandoned, despicable essence" (MEW 40, p. 385). Critique of domination and ideology is the consequence of this categorical imperative. Such an interpretation of Marx and Engels stresses that morals do not fade if injustice vanishes, but that there is a potential for the emergence of an alternative cooperative ethics/morality, a "really human morality" (MEW 40, p. 132).

Such a reading of the Marxian works implies the ethics of co-operation. Cooperation (as originally defined by Marx in Capital (MEW 23, pp. 344f, 350f) is a type of social relationship for achieving social integration that is different from competition. 
Co-operation is a specific type of communication, in which actors achieve a shared understanding of social phenomena, make concerted use of resources so that new systemic qualities emerge, engage in mutual learning, all actors benefit, and feel at home and comfortable in the social system that they jointly construct. We argue that co-operation in this sense is (or at least can be visualized as being) the highest principle of morality, it is the foundation of an objective dimension of ethics, a co-operative ethics. All human beings strive for happiness, social security, self-determination, self-realization, inclusion in social systems so that they can participate in decision processes, co-designing their social systems. Competition means that certain individuals and groups benefit at the expense of others, i.e. there is an unequal access to structures of social systems. This is the dominant organizational structure of modern society, modern society hence is an excluding society. Co-operation as it is understood here includes people in social systems, it lets them participate in decisions and establishes a more just distribution of and access to resources. Hence co-operation is a way of achieving and realizing basic human needs, competition is a way of achieving and realizing basic human needs only for certain groups and excluding others. Co-operation forms thus the essence of human society, while competition alienates humans from their essence. One can imagine a society that functions without competition, a society without competition is still a society. One cannot imagine a society that functions without a certain degree of co-operation and social activity. A society without co-operation is not a society, it is a state of permanent warfare, egoism and mutual destruction that sooner or later destroys all human existence. If co-operation is the essence of society then a truly human society is a co-operative society. Full co-operation is just another formulation for a participatory democracy. Cooperation as the highest principle of morality is grounded in society and social activity itself, it can be rationally explained within society and need not refer to a highest transcendental absolute principle such as God that cannot be justified within society. Co-operative ethics is a critique of lines of thought and arguments that want to advance exclusion and heteronomy in society, it is inherently critical, it subjects commonly accepted ideas, conventions, traditions, prejudices, and myths to critical questioning. It questions mainstream opinions and voices alternatives to them in order to avoid one-dimensional thinking and strengthen complex, dialectical, multidimensional thinking. Co-operation is the immanent essence of all societies, it is grounding human existence. Competitive class societies estrange society from its very essence. To transcend estrangement and the false state of society means to constitute transcendental political projects that struggle for the abolition of domination so that the immanent essence of society can be realized. This transcendence is grounded in society itself, i.e. in the co-operation process of humans. It is an immanent transcendence.

The notion of immanent transcendence as the dialectic of essence and existence is based in Hegel's notion of truth and actuality as correspondence of essence and existence. "Actuality is the unity, become immediate, of essence with existence, or of inward with outward" (Hegel, 1830, §142). Not all existence (Sein) is actual (Wirklichkeit), only existence that is reasonable corresponds to its essence and therefore has become true. It has already been mentioned that Marx saw the lack of control of the means of production, the labour process, and the results of labour by the immediate producers as an alienation of society and humans from their essence. "Estranged labour, therefore, turns man's species-being - both nature and his intellectual species-power - into a being alien to him and a means of his individual existence. It estranges man from his own body, from nature as it exists outside him, from his spiritual essence, his human existence" (MEW 40, p. 517).

One of the first critical scholars that have seen the logic of essence as foundation of immanent transcendence in the 20th century, was Herbert Marcuse (1932, p. 536): "The fact from which the critique and the interpretation set out was the alienation and estrangement of the human essence as expressed in the alienation and estrangement of labor, and hence the situation of man in the historical facticity of capitalism. This fact appears as the 
total inversion and concealment of what the critique had defined as the essence of man and human labor. (...) Regarding the situation and praxis from the standpoint of the history of man's essence makes the acutely practical nature of the critique even more trenchant and sharp: the fact that capitalist society calls into question not only economic facts and objects but the entire 'existence' of man and 'human reality' is for Marx the decisive justification for the proletarian revolution as total and radical revolution, unconditionally excluding any partial upheaval or 'evolution.' The justification does not lie outside or behind the concepts of alienation and estrangement - the justification is rather precisely this alienation and estrangement itself".

Crawford Brough Macphersons (1973) theory of participatory democracy is also based on the Marxian notion of essence. He considers the essence of humans as "the capacity for rational understanding, for moral judgement and action, for aesthetic creation or contemplation, for the emotional activities of friendship and love, and, sometimes, for religious experience" (= developmental power; Macpherson, 1973, p. 4). Participatory democracy would be the realization of human essence, which would presuppose the sublation of private property and the technological maximization of free time.

Next, it should be shortly outlined how one can apply the notion of immanent transcendence as dialectic of essence and existence to the notion of information.

\subsection{Critical information theory as immanent transcendence}

Scott Lash (2002) has argued that critical theory in the information society must be immanent critique because there would be no outside space for transcendental critical reflection due to the immediacy of information (the speed and ephemerality of information would leave almost no time for reflection), the spatiotemporal extension caused by informatization and globalization processes, the vanishing of boundaries between human and non-human and culture as well as between exchange value and use value. Information critique would have to be an immanent critique without transcendentals.
Critique of information would be in information itself, and it would be modest and also affirmative.

The arguments of a critical theory of information, as outlined thus far, proceed in a different way (cp. Fuchs, 2008): I argue that the information society has potentials for cooperation that provide a foundation for the full realization of the immanent essence of society - co-operation. Co-operation is seen as the very essence of society (an argument that can be found in the writings of young-Marx, Marcuse, and Macpherson), it is an immanent feature of society and the human being as such, but this potential is estranged in modern society. This immanence is in contemporary society transcendental because the existence of society is different from its essence. The information society promises a new transcendental space - a co-operative society (or participatory democracy) - that is immanent in society as such (but not existent in alienated societies) and potentially advanced by information and information technology. But such a society is not reached automatically because there is an antagonism between co-operation and competition immanent in capitalism and hence also in the capitalist information society that threatens the potentials for co-operation. Hence for establishing an outside of and alternative to global informational capitalism transcendental self-organizing political projects are needed which have alternative goals, practices, and structures of organization that however make use of existing structures (such as communication technologies) in order to transcend these very structures and create a new global space - a participatory democracy. Information produces potentials that undermine competition, but at the same time also produce new forms of domination and competition. The philosophical argument is based on the logic of essence and on the dialectic of immanence and transcendence. The line of argument assumes a formal identity of immanence and transcendence with society as the system of reference. Transcendence is not something that is externally given to being, but as immanent essence (and thus Wirklichkeit) of that being. Transcendentals are societal forces that represent needs and goals that form the 
immanence essence of society, but are repressed within the existing antagonistic totality and cannot be realized within it. Hence I do not agree with Lash that transcendental critique and dialectical critique (like the one of the Frankfurt school) are outdated. A dialectical framework of critique is needed for understanding the interconnected opportunities and risks of global informational capitalism. Facing Paul A. Taylor's (2006) critique that Lash's informationcritique is media-determinist and risks becoming uncritical and conformist due to the lack of transcendentals, Lash (2006) now seems to argue for the dialectic of immanence and transcendence. One of my main points is that due to informatization, the dialectics of thinkers like Hegel, Marx, and Marcuse gain a new topicality in transposed forms.

An example for critical information theory as immanent transcendence is the antagonistic form of information in contemporary capitalist economy. New media as such do not have clear-cut effects; they are antagonistically structured and embedded into the antagonisms of capitalist society. The antagonism between co-operation and competition that shapes modern society, limits self-determination and participation, also shapes the techno-social Internet system. Under the current societal conditions, which are characterized by the colonization of society by the instrumental logic of accumulation, risks and competitive forces dominate over realized opportunities, cooperation, and participation on the Internet. The dialectical antagonistic character of social and technical networks as motor of competition and cooperation in informational capitalism reflects Marx's idea that the productive forces of capitalism are at the same time means of exploitation and domination and produce potentials that go beyond actuality, point towards a radically transformed society, and anticipate a fully cooperative design of the means of production (Fuchs, 2008). The productive forces of contemporary capitalism are organized around informational networks (Fuchs, 2008).

It is due to three specific characteristics of such structures that they come in contradiction with the capitalist relations of production and are a germ form (keimform) of a society that is based on fully cooperative and socialized means of production:

1. Information as a strategic economic resource is globally produced and diffused by networks. It is a good that is hard to control in single places or by single owners.

2. Information is intangible. It can easily be copied, which results in multiple ownerships and hence undermines individual private property.

3. The essence of networks is that they strive for establishing connections. Networks are in essence a negation of individual ownership and the atomism of capitalism.

Informational networks both extend and undermine capital accumulation. Informational networks aggravate the capitalist contradiction between the collective production and the individual appropriation of goods. "The contradiction between the general social power into which capital develops, on the one hand, and the private power of the individual capitalists over these social conditions of production, on the other, becomes ever more irreconcilable, and yet contains the solution of the problem, because it implies at the same time the transformation of the conditions of production into general, common, social, conditions" (MEW 25, p. 274).

Networks are a material condition of a free association, but the cooperative networking of the relations of production is not an automatic result of networked productive forces, a true network society in the sense of an association of free and equal producers (MEW 18, p. 62) is something that people must struggle for and that they can achieve under the given conditions but that could very well also never emerge if the dominant regime will be successful in continuing its reign. Networks are forms of development as well as fetters of capitalism; paraphrasing Marx one can say that informational capitalism is a point where the means of production have become "incompatible with their capitalist integument" (MEW 23, p. 791).

The antagonistic economic character of network capitalism has two colliding sides, the cooperative one of the informational gift 
economy and the competitive one of the informational commodity economy.

Knowledge is in global network capitalism a strategic economic resource; property struggles in the information society take on the form of conflicts on the public or proprietary character of knowledge. Its production is inherently social, cooperative, and historical. Knowledge is in many cases produced by individuals in a joint effort. New knowledge incorporates earlier forms of knowledge; it is coined by the whole history of knowledge. Hence, it is in essence a public good and it is difficult to argue that there is an individual authorship that grounds individual property rights and copyrights. Global economic networks and cyberspace today function as channels of production and diffusion of knowledge commodities; the accumulation of profit by selling knowledge is legally guaranteed by intellectual property rights.

In society, information can only be produced jointly in cooperative processes, not individually. Hence, Marx argued that knowledge "depends partly on the cooperation of the living, and partly on the utilisation of the labours of those who have gone before" (MEW 25, p. 114). Whenever new information emerges, it incorporates the whole societal history of information, that is, information has a historical character. Hence, information in essence is a public good, freely available to all. But in global informational capitalism, information has become an important productive force that favours new forms of capital accumulation. Information is today not treated as a public good, but rather as a commodity. There is an antagonism between information as a public good and as a commodity.

If the grounding feature of information is that it is a social, historical, dynamic good, then its essence is its public character. According to Hegel, truth means the correspondence of essence and existence of a thing. So based on Hegel's logic of essence, one can argue that an information society, in which information is a commodity (informational capitalism) is a false information society because it restricts access and transforms information artificially into a private good. A true information society in contrast then is an information society, in which (among other qualities) knowledge is available to all for free and is co-produced in co-operation processes.

That informational capitalism is dominated by corporate interests can be visualized by figures like the following one: The total GDP of all 53 African states was 1000,913 billions US\$ in 2007 (data according to World Economic Outlook Online Database, April 2007, retrieved on June 25th 2007). The total assets of the top six knowledge corporations (AT\&T, Vodafone, Verizon, Deutsche Telekom, Nippon, Telefonica; calculation based on capital assets, Forbes 2000, 2007 Listing of Largest Coporations, March $29^{\text {th }}$ 2007) were 1132,41 billion US\$ in 2007 and hence are larger than the total African GDP. This shows the huge economic power of knowledge corporations. Knowledge that is produced, transmitted, and communicated with the help of technologies influences human thinking and decisions. Hence, the existing agglomeration of economic capital by knowledge corporations gives them a tremendous power for influencing human thinking and decisions. They control definitions of reality and are able to create one-dimensional views of reality that neglect negation and critique of dominant views that represent dominant interests. Corporate power allows the control of worldviews, labour and quality standards, markets, political power, prices, technological standards, and consumer behaviour. Proprietary models that aim at accumulating capital with the help of media like the Internet form the dominant reality of informational capitalism.

However, an alternative production model has been developed that to certain degrees challenges capitalism and sees economic goods not as property that should be individually possessed but as common goods to which all people should have access and from which all should benefit. This model stresses open knowledge, open access, and cooperative production forms; it can, for example, be found in virtual communities like the free software community that produces the Linux operating system, which is freely accessible and to which, due to the free access to the source code of its software 
applications, people can easily contribute. The open access principle has resulted in global open-source production models where people cooperatively and voluntarily produce digital knowledge that undermines the proprietary character of knowledge (if knowledge is free and of good quality, why should one choose other knowledge that is expensive?). The open-source principle has also been applied to other areas, such as online encyclopaedias (e.g. Wikipedia) and online journalism (e.g. Indymedia).

Open-source software has been realized mainly within projects such as the Linux operating system. Special licenses (termed copy-left) such as the GNU public license have been developed for assuring that free software has an open access to its source code. Free software hardly yields economic profit; it is freely available on the Internet and constitutes an alternative model of production that questions proprietary production models.

Digitization allows the easy copying of knowledge such as texts, music, images, software, and videos. The Internet enables the fast and free global distribution of knowledge with the help of technologies such as peer-to-peer-networks (Napster, Audiogalaxy, KaZaA, KaZaA Lite, LimeWire, Morpheus, Edonkey, WinMX, iMesh, Bearshare, Blubster, SoulSeek, BitTorrent, Overnet, Toadnode, Grokster, etc.). The informational content can be stored on different physical carriers; the possession of digital information by one person does not imply the nonpossession of it by others. Recording Industry Association of America (RIAA) sues operators of such network applications, but whenever one operator has been forced to quit its services, others have emerged. This shows that information and informational networks like the Internet are hard to control and are embedded into social struggles on the public or private character of information.

Two poles of a dialectic are not only separated and different, they also are entangled, meshed, and encroach each other (Holz, 2005). In the case of gifts and commodities, this means that the gift form is subsumed under the commodity form and can even be used directly for achieving profit.
There is a commodified Internet economy and a noncommodified Internet economy. Only those aspects of the Internet economy that are nonprofit gifts, that just have use value and no exchange value, hence are provided without costs for the users and without selling advertisement space, can be considered as decommodified or noncommodified. Examples are file-sharing platforms, Wikipedia, Linux, and Indymedia. Commodified Internet spaces are always profit oriented, but the goods they provide are not necessarily exchange values and market oriented; in some cases (such as Google, Yahoo, MySpace, YouTube, Netscape), free goods or platforms are provided as gifts in order to drive up the number of users so that high advertisement rates can be charged in order to achieve profit. In other cases, digital or nondigital goods are sold with the help of the Internet (e.g., Amazon), or exchange of goods is mediated and charged for (online marketplaces such as eBay or the Amazon Marketplace). In any of these cases the primary orientation of such spaces is instrumental reason, that is, the material interest of achieving money profit, a surplus to the invested capital.

In the early phase of the World Wide Web, platforms that have provided content were important business models. Many new stock companies in the areas of Internet content and Internet services had emerged since the mid-1990ies. By the years 2005 and 2006, accumulation strategies related to the Internet had shifted from a primary focus on information to a focus on communication and cooperation (Fuchs, 2008). Some scholars like to designate this transformation as emergence of "Internet 2.0" and "Web 2.0", although the main background behind using these terms seem to be marketing strategies for boosting investment. The most characteristic example of "Web 2.0" are social networking platforms like MySpace, StudiVZ, or Facebook that allow the online maintenance and establishment of social relationships by an integrated use of technologies like e-mail, websites, guest books, forums, digital videos, or digital images. So e.g. MySpace is a Web platform that allows users to generate personal profiles, on which they can upload pictures, 
text, videos, music, and keep their personal blogs. It networks users with a friendship system (users can add others to their friend list and post comments to their friends' guest books), discussion forums, interest groups, chat rooms, and a mail function.

Commercial "Web 2.0" applications are typically of no charge for users; they generate profit by achieving as many users as possible by offering free services and selling advertisement space to third parties and additional services to users. The more users, the more profit, that is, the more services are offered for free, the more profit can be generated. Although the principle of the gift points towards a postcapitalist society, gifts are today subsumed under capitalism and used for generating profit in the Internet economy. The Internet gift economy has a double character; it supports and at the same time undermines informational capitalism. Applications such as file-sharing software question the logic of commodities, whereas platforms such as Google and MySpace are characteristic for the capitalist gift economy. Internet 2.0 is characterized by this antagonism between information commodities and information gifts.

The Internet gift commodity economy can be read as a specific form of what Dallas Smythe (1981/2006) has termed the audience commodity. He suggests that in the case of media advertisement models the audience is sold as a commodity. "Because audience power is produced, sold, purchased and consumed, it commands a price and is a commodity. (...) You audience members contribute your unpaid work time and in exchange you receive the program material and the explicit advertisements" (Smythe, 1981/2006, pp. 233, 238). Audiences would work, although unpaid; the consumption of the mass media would be work because it would result in a commodity, hence it would produce that commodity. Also the audience work would include "learning to buy goods and to spend their income accordingly", the demand for the consumption of goods, and the reproduction of their own labour power (Smythe, 1981/2006, p. 243f).

With the rise of user-generated content and free access social networking platforms like
MySpace or Facebook and other free access platforms that yield profit by online advertisement, the web seems to come close to the accumulation strategies employed by capital on traditional mass media like TV or radio. The users who google data, upload or watch videos on YouTube, upload or browse personal images on Flickr, or accumulate friends with whom they exchange content or communicate online on social networking platforms like MySpace or Facebook, constitute an audience commodity that is sold to advertisers. The difference between the audience commodity on traditional mass media and on the Internet is that in the latter the users are also content producers, there is user-generated content, the users engage in permanent creative activity, communication, community building, and content-production. That the users are more active on the Internet than in the reception of TV or radio content is due to the decentralized structure of the Internet that allows many-to-many communication. Due to the permanent activity of the recipients and their status as prosumers, I would in the case of the Internet argue that the audience commodity is a prosumer commodity. The category of the prosumer commodity does not signify a democratization of the media towards participatory systems, but the total commodification of human creativity. Much of the time spent online produces profit for large corporations like Google, NewsCorp (which owns MySpace), or Yahoo (which owns Flickr). Advertisements on the Internet are frequently personalized. This is possible by surveilling, storing, and assessing user activities with the help of computers and databases. This is another difference to TV and radio, which due to their centralized structure provide less individualized content and advertisements. But also in the area of the traditional mass media one can observe a certain shift as e.g. in the case of pay per view, televotings, talkshows, and call-in TV and radio shows. In the case of the Internet the commodification of audience participation is easier to achieve than on other mass media. The rise of the Internet prosumer commodity also shows that the visions of critical theorists like Benjamin, Brecht, or Enzensberger of an emancipatory media 
structure that emerges from prosumption has today been subsumed under capital. New media certainly carry a certain potential for advancing grassroots socialism, but this potential is antagonistically entangled into the dominant structures and it is unclear if the capitalist integument can be stripped off. Personalized advertisement on the Internet is an expression of the tendency towards what Deleuze (1995) has termed the "society of control" as aspect of contemporary marketing and capitalism in the sense that individuals are activated to continuously participate in and integrate themselves into the structures of exploitation (cf. Fuchs 2008, p. 149f), during as well as outside of wage labour time.

The more users make use of advertisement-based free online platforms and the more time they spend online producing, consuming, and exchanging content, communicating with others, the higher the value of the prosumer commodity they produce will become, the higher the advertisement prices will rise, and the higher the profits of the specific internet corporations will become. "The price that corporations pay for advertising spots on particular programmes is determined by the size and social composition of the audience it attracts" (Murdock \& Golding, 2005, p. 65).

In Web 2.0, social relationships are commodified. Non-commercial non-profit open source platforms that focus on social and political networking pose an alternative. Social networking has possibilities for groupformation and co-operation, but individualized communication and corporate interests shape its dominant form. The social potential that emerges from these sites could be channelled into collective political projects.

The basic business models that dominate the Web are the advertising model, selling services to users, and combinations of the two (Fuchs, 2008). That the first model is the dominant one can be seen from the fact that nine out of the ten most accessed Web platforms make use of it for accumulating capital: 1. Yahoo!, 2. Google, 3. YouTube, 4.+5. Windows Live Search and Microsoft Network (MSN), 6. Myspace, 8. Facebook, 9. Blogger, 10. Yahoo Japan (data from Alexa Global Top 500 (alexa.com), accessed on
August 6, 2008). The only exception is Wikipedia (\#7), which is non-profit oriented.

Figure 1 shows the rapid growth of Internet advertising profits in the USA. These profits amounted to 21.2 billion US\$ in 2007, which make up $11.0 \%$ of the total US advertising profits (Source: IAB Internet Advertising Revenue Report 2007). The online advertising profits were higher than the profits made by radio- and cable TV-advertising in 2007 and were only exceeded by profits in newspaperand TV Distribution-advertising (lbid.).

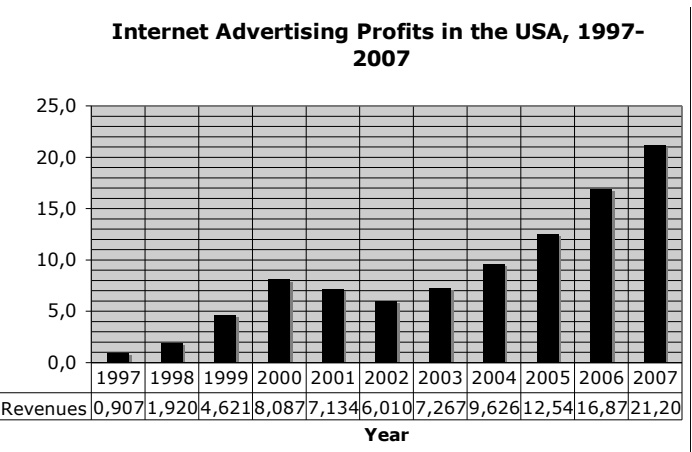

Figure 1: Internet Advertising Profits in the

USA (Data Source: IAB Internet Advertising

Revenue Report 2007, revenues in billion US\$)

Giving something for free to others is an idea that transcends capitalism because capitalism is based on exchange value, the exchange of money for commodities and commodities for money so that capital can be accumulated. Exchange negates freedom, giving without taking. Therefore the open access and open content principle anticipates a noncommodified society, in which all goods are provided for free due to a high productivity that allows the maximization of free time. In such a society, information and other use values are no longer treated as individualized private property, but as collective property that is co-operatively produced. For Marx, communism was not the dictatorship of the proletarians (a phrase introduced by Engels), but a fully co-operative society. Marx speaks of communism as "the co-operative society based on common ownership of the means of production" (MEW 19, p. 19), in which "the springs of co-operative wealth flow more abundantly" (MEW 19, p. 21). The example of social networking platforms and the accumulation strategy of the Internet gift commodity economy shows that gifting and 
co-operation as transcendence do not stand outside of capitalism, but have become subsumed under capitalist commodification mechanisms. The very phenomenon that gives us hope for transformation at the same time is currently completely immanent to capitalism and functions as accumulation principle. To gain a transcendental dimension that allows going beyond capitalism, information gifts need to become part of political struggles for a communist, i.e. cooperative, information society.

The relation of immanence and transcendence is a foundational problem of critical theory. Another foundational problem is the relation of base and superstructure. This issue will be discussed next by taking a look at a debate between Nancy Fraser and Axel Honneth.

\section{The debate on redistribution and recognition: The problem, of base and superstructure in critical (information) theory}

\subsection{Fraser and Honneth: The debate on redistribution and recognition as a reframing of the problem of base and superstructure in critical theory}

The question how economy (base) and polity/culture (superstructure) are related is an old problem of critical theory. It has recently been renewed by a debate within critical theory on the categories of redistribution of economic resources and recognition of cultural identities between Nancy Fraser and Axel Honneth (2003). Tables 5 and 6 summarize the two approaches.

Both Fraser and Honneth question the uncoupling of political demands for the recognition of identities from demands for redistribution.

For Fraser, gender-, race-, and classdomination are two-dimensional categories that have economic and cultural aspects. For her, all three categories are processes of malrecognition of status and maldistribution. "For practical purposes, then, virtually all realworld axes of subordination can be treated as two-dimensional. Virtually all implicate both maldistribution and misrecognition in forms where each of those injustices has some independent weight, whatever its ultimate roots. To be sure, not all axes of subordination are two-dimensional in the same way, nor to the same degree. Some, such as class, tilt more heavily toward the distribution end of the spectrum; others, such as sexuality, incline more to the recognition end; while still others, such as gender and 'race,' cluster closer to the center" (Fraser \& Honneth, 2003, p. 25).

Fraser treats economy and culture, maldistribution and malrecognition, as two equal levels of society and domination. Her position of perspectival dualism sees the two poles as impinging on one another (Fraser \& Honneth, 2003, p. 64). Her approach is a form of interactive dualism, in which two phenomena are autonomous, but interact in certain cases. In contrast, in a dialectic relationship two phenomena form a differentiated unity in plurality, which means that they necessarily encroach each other and that there is a force that besides the difference creates a certain unity (cp. Holz, 2005). My suggestion is to see the economy as the sphere of society that forms this unity in society and class as the process that forms this unity in processes of domination. Economy and class are foundations of society and domination. In contemporary society, you can act outside and without certain forms of malrecognition, for example by implementing gender parity or a fifty-fifty sharing of housework you can achieve gender equality in institutions and households without having necessarily to abolish the capitalist system. A capitalist system without patriarchy and racism is in principle imaginable, but not one without class. In such a system, men and women, people with different sexualities and different ethnic background are all recognized as being equally valuable for attaining positions as owners, managers, and workers. There is no status malrecognition based on gender, sexuality, or race, but certainly a class exploitation and class malrecognition, in which exploiters engage equally in exploiting labour. Gender and race always have a class aspect, but class exploitation (frequently, but) not always and not necessarily has aspects of patriarchy and racism. The economy is the foundation of society that forms a necessary, 
but not a sufficient condition for the existence of the political and the cultural system. It sets limits and exerts pressures on these systems, which feed back onto the economic foundation. Equal recognition of certain identities is compatible with class exploitation. Especially in an age that is dominated by the neoliberal intensification of socio-economic inequality that affects ever more people, it is important to stress the specific role of class and the capitalist economy in contemporary society. Fraser argues for a unity of demands for recognition and redistribution in political struggles ("no redistribution without recognition", "no recognition without redistribution", Fraser \& Honneth, 2003, pp. $65 f)$. This stress is important, but neglects that redistribution must always be a foundation for recognition, whereas cultural recognition of different identities is not always a foundation for redistribution, but can also act as a foundation for more socio-economic inequality, which shows a certain order of valences. Fraser refuses to ground her approach in one general normative principle, but wants to provide "multiple points of entry into social reality" (Fraser \& Honneth, 2003, p. 205). The problem with such an approach is that is establishes a plurality without unity. Fraser gives good examples for how class infuses racism and patriarchy (Fraser \& Honneth, 2003, pp. 58, 64, 83f), whereas the examples with which she tries to show that sexual subordination impinges on class subordination are much less convincing (Fraser \& Honneth, 2003, p. 65, 84).

Axel Honneth in my opinion is right in pointing out that Fraser gives no reasons why she conceives society as consisting of economy and culture (Fraser \& Honneth, 2003 , pp. 156, 179). One could especially add the political system because everyday processes do not only consist of economic production and cultural values, but also of the reaching of binding collective decisions, by which all members of collectives are affected.
To be precise, one must say that Fraser mentions the possibility of a political realm of society that is confronted by the problem of political marginalization that can be solved by processes of democratization (Fraser \& Honneth, 2003, p. 68). But she only introduces this idea ex-post as concluding reflection, after having introduced social theory foundations that focus on economy and culture and where political aspects are missing.

Fraser argues for deep economic and cultural transformations. In the economic realm, this would be the perspective of socialism: "In today's neoliberal climate especially, it is important to retain the general idea of economic transformation, even if we are currently uncertain of its precise institutional content" (Fraser \& Honneth, 2003, p. 75). Fraser's cultural deconstructivism in my opinion is too radical. It suggests that all status distinctions are "oppressive per se" (Fraser\& Honneth, 2003, p. 76). The danger here is that difference as such is considered as always oppressive, and that the goal is not only to blur the boundaries, but to eliminate the differences between men and women, homosexual and heterosexual, animals and humans, technology and humans as is suggested e.g. by cyborg-politics, the animal liberation movement, or actor network theory. Certain differences are sources of oppression in stratified societies, but can be a source of pleasure in a liberated society. The problem is not difference as such, but oppressive difference. Especially the blurring of the boundaries between humans, animals, and technologies, as undertaken by cyborg theory, animal liberation activists, and actor network theory, is a dangerous endeavour because it risks reducing humans to the status of animals or machines in an instrumental, antihumanist and potentially biologistic or technocratic way that could erect new fascist forms of domination. 
Table 5: Nancy Fraser's Perspectival Dualism (Fraser \& Honneth, 2003, chapter 1)

\begin{tabular}{|c|c|c|c|c|}
\hline $\begin{array}{l}\text { Sphere of } \\
\text { Society }\end{array}$ & Moral Values & Problems & Political Process & $\begin{array}{l}\text { Principle(s) of } \\
\text { Morality }\end{array}$ \\
\hline Economy & $\begin{array}{l}\text { Distributive justice: "The } \\
\text { distribution of material } \\
\text { resources must be such } \\
\text { as to ensure participants' } \\
\text { independence and } \\
\text { 'voice'. (..) It precludes } \\
\text { forms and levels of } \\
\text { economic dependence } \\
\text { and inequality" (p. 36). }\end{array}$ & $\begin{array}{l}\text { Class subordination: socio- } \\
\text { economic inequality and } \\
\text { maldistribution (pp. 13, 19), } \\
\text { "social arrangements that } \\
\text { institutionalize deprivation, } \\
\text { exploitation, and gross } \\
\text { disparities in wealth, income, } \\
\text { and leisure time, thereby } \\
\text { denying some people the } \\
\text { means and opportunities to } \\
\text { interact with others as peers" } \\
\text { (p. } 36) \text {. }\end{array}$ & $\begin{array}{l}\text { Redistribution of } \\
\text { wealth: class } \\
\text { politics }\end{array}$ & $\begin{array}{l}\text { Participatory parity: } \\
\text { "According to this } \\
\text { norm, justice requires } \\
\text { social arrangements } \\
\text { that permit all (adult) } \\
\text { members of society to } \\
\text { interact with one } \\
\text { another as peers" ( } p \text {. } \\
\text { 36). }\end{array}$ \\
\hline Culture & $\begin{array}{l}\text { Reciprocal recognition, } \\
\text { status equality: } \\
\text { Institutionalized patterns } \\
\text { "constitute actors as } \\
\text { peers, capable of } \\
\text { participating on a part } \\
\text { with one another in social } \\
\text { life" (p. 29). }\end{array}$ & $\begin{array}{l}\text { Status subordination: cultural } \\
\text { domination, misrecognition of } \\
\text { status, disrespect for } \\
\text { identities (pp. 13, 19), } \\
\text { "Institutionalized patterns of } \\
\text { cultural value constitute } \\
\text { some actors as inferior, } \\
\text { excluded, wholly other, or } \\
\text { simply invisible" (p. 29). }\end{array}$ & $\begin{array}{l}\text { Recognition of } \\
\text { different identities: } \\
\text { identity politics } \\
\text { (gender, sexuality, } \\
\text { nationality, } \\
\text { ethnicity, race) }\end{array}$ & \\
\hline
\end{tabular}

Table 6: Axel Honneth's Normative Monism (Fraser \& Honneth, 2003, chapter 2)

\begin{tabular}{|c|c|c|c|c|}
\hline $\begin{array}{l}\text { Sphere of } \\
\text { Society }\end{array}$ & Moral Values & Problems & Political Process & $\begin{array}{l}\text { Principle(s) of } \\
\text { Morality }\end{array}$ \\
\hline $\begin{array}{l}\text { Intimate } \\
\text { relationships }\end{array}$ & $\begin{array}{l}\text { Love: } \\
\text { Recognition of } \\
\text { needs }\end{array}$ & $\begin{array}{l}\text { Denial of } \\
\text { emotional } \\
\text { attachment or } \\
\text { disrepect of a } \\
\text { person's physical } \\
\text { integrity } \\
\text { (Honneth, 1992, } \\
\text { pp. 193, 190) }\end{array}$ & $\begin{array}{l}\text { Surplus of validity of recognition of } \\
\text { love (socialization): "Moral progress } \\
\text { in the sphere of love might then } \\
\text { mean a step-by-step elimination of } \\
\text { the role-clichés, stereotypes, and } \\
\text { cultural ascriptions that structurally } \\
\text { impede adaptation to others' needs" } \\
\text { (p. 188) }\end{array}$ & $\begin{array}{l}\text { Recognition of needs, } \\
\text { emotional recognition, } \\
\text { love }\end{array}$ \\
\hline Legal relations & $\begin{array}{l}\text { Legal equality: } \\
\text { Recognition of } \\
\text { equal legal } \\
\text { treatment }\end{array}$ & $\begin{array}{l}\text { Structural } \\
\text { exclusion from or } \\
\text { denial of the } \\
\text { possession of } \\
\text { certain rights } \\
\text { (Honneth. 1992, } \\
\text { pp. 190, 194) }\end{array}$ & $\begin{array}{l}\text { Surplus of validity of recognition of } \\
\text { legal equality (legalization): } \\
\text { "expanding the principle of equal } \\
\text { legal treatment" (p. 188) }\end{array}$ & $\begin{array}{l}\text { Recognition of legal } \\
\text { equality, universalism }\end{array}$ \\
\hline Labour & $\begin{array}{l}\text { Social esteem: } \\
\text { Recognition of } \\
\text { achievements }\end{array}$ & $\begin{array}{l}\text { Denial of social } \\
\text { acceptance that } \\
\text { enables self- } \\
\text { esteem } \\
\text { (Honneth, 1992, } \\
\text { pp. 191, 195) }\end{array}$ & $\begin{array}{l}\text { Surplus of validity of recognition of } \\
\text { social esteem: Moral progress in the } \\
\text { sphere of social esteems means } \\
\text { "radically scrutinizing the cultural } \\
\text { constructions that, in the industrial- } \\
\text { capitalist past, saw to it that only a } \\
\text { small circle of activities were } \\
\text { distinguished as 'gainful } \\
\text { employment"' (p. 188) }\end{array}$ & $\begin{array}{l}\text { Recognition of } \\
\text { achievements, } \\
\text { solidarity, sympathy }\end{array}$ \\
\hline
\end{tabular}


Nancy Fraser grounds a pluralistic theory of society that is missing a certain sense for unity. But she is also right in my opinion in arguing that Axel Honneth advances "a reductive culturalist view of distribution" (Fraser \& Honneth, 2003, p. 34). Honneth argues that with the exception of Habermas and Gramsci, critical theory has had a tendency to anti-normativism (Fraser \& Honneth, 2003, pp. 128f). The greatest problem for humans would be the "withdrawal of social recognition, in the phenomena of humiliation and disrespect" (Fraser \& Honneth, 2003, p. 134). Whereas Fraser wants to base critical theory on two equal dual categories, redistribution and recognition, Honneth looks for a normative monism that is based on one central category, the one of recognition. He bases his theory on the assumption that humans are psychological beings that strive for "self-confidence, selfrespect, and self-esteem" (Honneth, 1992, p. 196) and suffer if they are disrespected. A moral-theoretical monism would be needed because "the central institutions of even capitalist society require rational legitimation through generalizable principles of reciprocal recognition, their reproduction remains dependent on a basis of moral consensus which thus possesses real primacy vis-à-vis other integration mechanisms" (Fraser \& Honneth, 2003, p. 157). He subdivides recognition into three forms (love, equality, achievement). Honneth argues that especially achievement has been problematic right from the start of modern society because it is part "of an influential ideology insofar as it simply expressed the one-sided value horizon of those social groups which, because they possessed capital, had the means to reorganize economic reproduction. Thus, what 'achievement' means, and what guarantees a just distribution of resources, was measured right from the start against an evaluative standard whose highest reference point was investment in intellectual preparation for a specific activity" (Fraser \& Honneth, 2003, p. 147). Distribution struggles are for Honneth "a specific kind of struggle for recognition, in which the appropriate evaluation of the social contributions of individuals or groups is contested" (Fraser \& Honneth, 2003, p. 171). The overall aim of society for Honneth is "enabling individual self-realization" (Fraser \& Honneth, 2003, p. 177).

For Honneth, morality is the foundation of society. This assumption explains his strong emphasis on recognition. Protest would be based on "moral conviction" (Fraser \& Honneth, 2003, p. 157). Fraser accordingly argues that Honneth inflates the concept of recognition "beyond all recognition" (Fraser \& Honneth, 2003, p. 201). She characterizes his approach as "moral psychology of prepolitical suffering" (Fraser \& Honneth, 2003, p. 202). There are certainly values and conflicting values in all social relations and struggles. So for example workers striking for wage increases or against lay-offs have different values than their employers. Nonetheless the central aspect of the conflict is not the definition of values, but the distribution of money. An immediate need for survival that has become threatened drives the protests, not conflicting value patterns, which are a result of objective material conditions. Certainly all institutions, as argued by Honneth, have moral aspects, but also all of them have economic aspects, there are no institutions without resources. Value patterns determine how these resources are distributed, but in order to form such values, resources first need to exist.

Honneth criticizes Fraser for her ungrounded assumption of economy and culture as the two spheres of society. But in his own approach, he also does not argue why he assumes the existence of the three spheres of personal relations, law, and labour. These three spheres could roughly be equated to culture, politics, and economy. But civil society is missing in the political system, and the cultural system lacks institutions such as the mass media, the education system, science, the medical system, or religion. Honneth provides just like Fraser an incomplete and ungrounded model of society.

Despite his monistic claim, Honneth argues in the end that his conception of justice is pluralistic because it is based on three principles (Fraser \& Honneth, 2003, p. 258). There is a strange and unresolved tension between monistic recognition and pluralism in Honneth's approach. If his intention were to 
argue dialectically, then he could say that monism and pluralism can be dialectically united in the figure of unity in plurality (a plurality of spheres and principles united by the category of recognition), but he does not do that. It is the other way round with Fraser: She argues for a pluralistic approach with two spheres, but ends up postulating one overall principle of participatory parity without arguing dialectically.

\subsection{Base and superstructure reconsidered: Towards a dialectical model of Society and a dialectic- materialistic moral philosophy}

How should the relation of base and superstructure be best conceived?

Models of society that see society as being composed of independent subsystems, such as Luhmann's (1984) theory of functional differentiation, face the problem of explaining phenomena that are characteristic for the global network society. So they e.g. cannot adequately grasp in his theory that today economic logic influences large parts of society. In contrast to reductionistic and relativistic social theories, dialectical social theories have proved successful in conceiving society as being composed of relative autonomous subsystems that all have their own specificity, but nonetheless depend on each other and influence each other. The subsystems are conceived as distinct and at the same time mutually interdependent, which is the fundamental logical figure of dialectical thinking.

Society can be conceived as consisting of interconnected subsystems that are not independent and based on one specific function they fulfil, but are open, communicatively interconnected, and networked. The ecological system, the technological system, the economic system, the political system, and the cultural system can be conceived as the subsystems of a model of society (Fuchs, 2008, cf. figure 2). Why exactly these systems? In order to survive, humans in society have to appropriate and change nature (ecology) with the help of technologies so that they can produce resources that they distribute and consume (economy), which enables them to make collective decisions (polity), form values, and acquire skills (culture). The core of this model consists of three systems (economy, polity, culture). This distinction can also be found in other contemporary sociological theories: Giddens (1984, pp. 2834) distinguishes economic institutions, political institutions, and symbolic orders/ modes of discourse as the three types of institutions in society. Bourdieu (1986) speaks of economic, political, and cultural capital as the three types of structures in society. Jürgen Habermas (1981) differentiate between the lifeworld, the economic system, and the political system. Each of these systems is shaped by human actors and social structures that are produced by the actors and condition the actors' practices. Each subsystem is defined and permanently re-created by a reflexive loop that productively interconnects human actors and their practices with social structures.

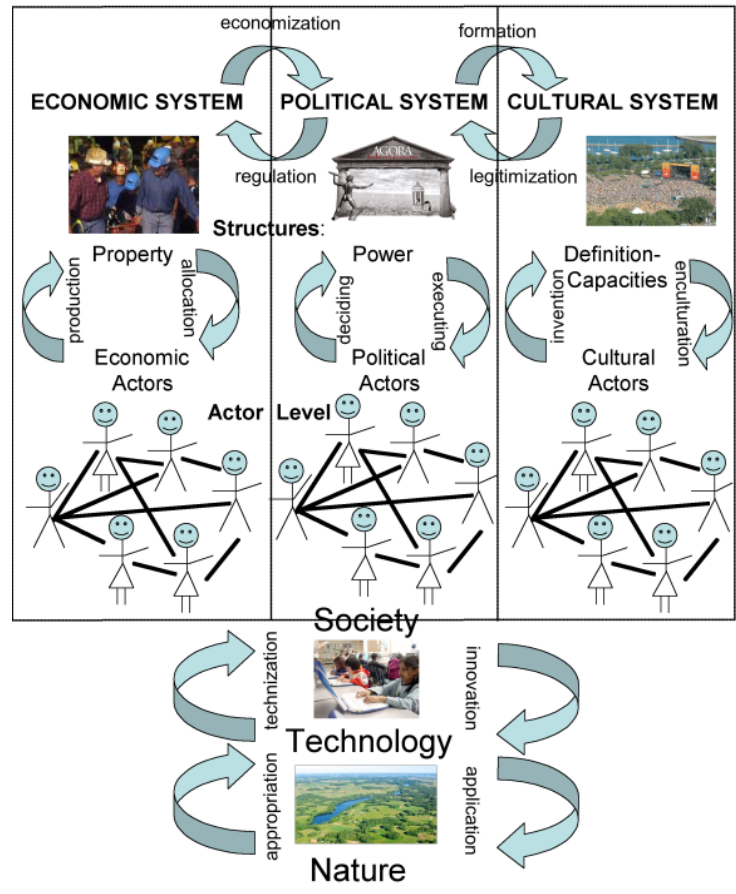

Figure 2: Society as dynamic, dialectical system (Source: Fuchs, 2008)

The economic system can only produce goods that satisfy human needs by human labour power that makes use of productive and communication technologies in order to establish social relations and change the state 
of natural resources. The latter are transformed into economic goods by the application of technologies to nature and society in labour processes. Hence the economy is based on a dialectic of natural resources and labour that is mediated by technology. We hence can argue that socially transformed nature and technology are aspects of the economic system.

This allows us to make a distinction between the base and the superstructure of society. The economic base is constituted by the interplay of labour, technology, and nature so that economic goods are produced that satisfy human needs. The superstructure is made up by the interconnection of the political and the cultural system so that immaterial goods emerge, which allow the definition of collective decisions and societal value structures. Does it make sense to speak of base (nature, technology, economy) and superstructure (polity, culture) in society, or does this mean that one reduces all social existence to economic facts? The superstructure is not a mechanic reflection, that is, a linear mapping, of the base, that is, the relations and forces of production. It cannot be deduced from or reduced to it. Orthodox Marxism for a long time did not realize this. That the base is not the mechanic reflection of the superstructure has for a long time not been realized by Idealism. All human activity is based on producing a natural and social environment; it is in this sense that the notion of the base is of fundamental importance. We have to eat and survive before we can and in order to enjoy leisure, entertainment, arts, and so on. We will survive for a while without leisure, art, entertainment, education, and decision-making, but only for a very short time without water and food. This shows that the economy is more fundamental and grounding in society than the political and the cultural system. The base is a precondition, a necessary but not sufficient condition for the superstructure. The superstructure is a complex, nonlinear creative reflection of the base, the base a complex, nonlinear creative reflection of the superstructure. This means that both levels are recursively linked and produce each other; economic practices and structures trigger political and cultural processes; cultural and political practices and structures trigger economic processes. The notion of creative reflection grasps the dialectic of chance and necessity/indetermination and determination that shapes the relationship of base and superstructure. There is not a content of the superstructure that is "predicted, prefigured and controlled" by the base; the base, as Raymond Williams in his famous paper on Base and Superstructure in Marxist Cultural Theory says, "sets limits and exerts pressure" on the superstructure (Williams, 2001, p. 165). Stuart Hall (1983) has in this context spoken of a determination in the first instance exerted by the economic system on superstructures.

What are the implications of a dialectical model of base and superstructure for the notion of information? If we conceive information as an integrative notion, then it must dialectically stretch across base and superstructure. This means that it is neither just an economic resource (e.g. information technology), nor just ideas, but should best be conceived as both objective and subjective. This can be achieved by defining information as a process of cognition, communication, and co-operation (Hofkirchner, 2002; Fuchs, 2008). It is a relationship that connects agents in a productive way so that they can produce novelty. It is the dynamic aspect of social systems. This then means that all three outlined subsystems have aspects of information, aspects of cognition, communication, and co-operation: In order to produce goods, humans need plans, communicative co-ordination of production, and co-operative labour processes. In order to take collective decisions, political opinions, political interaction, and actual decisionprocedures involving many actors are needed. In order to establish collective norms, individual worldviews, moral discourse, and the emergence of collective identities are needed. A critical theory of information questions conditions, in which structural resources such as property, decision-making capacities, value definition-capacities are asymmetrically distributed, certain actors are excluded from participation, and the one derive benefits at the expense of others.

We can speak of participation in cases, where humans are enabled by technologies, resources, organizations, and skills to design 
and manage their social systems all by themselves and to develop collective visions of a better future so that the design of social systems can make use of their collective intelligence (Fuchs, 2008). A participatory social system is a system, in which power is distributed in a rather symmetrical way, that is, humans are enabled to control and acquire resources such as property, technologies, social relationships, knowledge, and skills that help them in entering communication and cooperation processes in which decisions on questions that are of collective concern are taken. Providing people with resources and capacities that enable responsible and critical activity in decision-making processes is a process of empowerment; participation is a process of empowering humans.

How are participation, co-operation, and sustainability connected? Participation is structure-oriented, it is a process in which social structures are designed in such a way that individuals are included in the constitution of the social systems they live in and actually take part in these constitution processes. Cooperation is an intersubjective process within participatory structures. Participation is a logical and necessary, but not sufficient precondition for co-operation. Co-operation is the social process by which sustainable systems can be produced. Sustainability concerns the long-term form and effects of a social system. Participation means the structural enablement, co-operation the intersubjective social process, sustainability the long-term condition and effects of social systems, in which all benefit and have a good life. Abstractly spoken, a participatory, cooperative, and sustainable society is a society that guarantees a good life for all. A participatory, co-operative and sustainable information society (PCSIS) is a society in which knowledge and technology are together with social systems shaped in such ways that humans are included in and self-determine their social systems collectively, interact in mutually benefiting ways, and so bring about a long-term stability that benefits all present and future generations and social groups. Such a society is necessarily non-capitalistic and non-dominative. The next table shows the various dimensions of such a society.
Recognition in this model is a cultural process that produces wisdom. Redistribution can be considered as not just an economic process, but as the process of establishing a more participatory society by redistributing economic resources, power, and definitioncapacities from dominant groups to oppressed groups. Recognition is a cultural redistribution process. But these processes are not independent. Similarly, democratization is a redistribution of political power. Establishing a more fair society requires as a material foundation the redistribution of economic resources. A just society can only be a society, in which private property of the means of production cease to exist and all humans have enough material resources to live in wealth. Equity is a foundation for redistribution on the superstructure. Superstructural redistribution without redistribution at the base is an incomplete process, just like the other way around. Political redistribution means to give power to the powerless. A free society is one, in which all affected persons are involved in decisionmaking. Cultural redistribution means to abolish cultural status hierarchies that privilege the worldviews of certain groups or individuals in the formation of collective identities. A society is only wise if all people can have a voice that is heard and is active part of collective identity-formation processes. Class relations play an important role in this moral-philosophical model because the establishment of a more participatory society requires as a foundation material equity, i.e. the abolition of class. Without economic resources, people will not have influence in decision-making and cultural recognition becomes an empty phrase. But equity is not enough. It is a necessary, but not a sufficient condition for a participatory society. Collective decision-making and collective identity formation require resources as their foundations. If these processes shall be free and wise, then first of all the establishment of a classless society is needed. Democracy and identity politics are empty phrases in a capitalist society if they do not acquire an anticapitalist dimension. 
Table 7: Dimensions of a moral philosophy that is based on immanent transcendence

\begin{tabular}{|c|c|}
\hline Dimension & Definition \\
\hline Ecology: preservation & $\begin{array}{l}\text { Under the condition of ecological preservation, nature is treated by } \\
\text { humans in ways that allow flourishing of natural systems, i.e. the } \\
\text { autopoiesis of living systems is maintained and not artificially } \\
\text { interrupted or destroyed and natural resources are preserved and not } \\
\text { depleted. }\end{array}$ \\
\hline Technology: human-centredness & $\begin{array}{l}\text { That technology is human-centred means that technological systems } \\
\text { should help humans in solving problems, fit their capabilities, practices } \\
\text { and self-defined needs, support human activities and co-operation, and } \\
\text { involve users in definition, development, and application processes. }\end{array}$ \\
\hline Economy: equity & $\begin{array}{l}\text { Economic equity means that there is wealth for all, i.e. defined material } \\
\text { living standards should be guaranteed for all as a right, nobody should } \\
\text { live in poverty, and the overall wealth should be distributed in a fair way } \\
\text { so to avoid large wealth and income gaps between the most and the } \\
\text { least wealthy. }\end{array}$ \\
\hline Polity: freedom & $\begin{array}{l}\text { Freedom can in line with the critical-realist thinking of Roy Bhaskar } \\
\text { (1993) be conceived as the absenting of domination, i.e. the } \\
\text { asymmetrical distribution of power, so that humans are included and } \\
\text { involved in defining, setting, and controlling the conditions of their lives. } \\
\text { It is the absenting of constraints on the maximum development and } \\
\text { realization of human faculties. Freedom then means the maximum use } \\
\text { and development of what C.B. Macpherson (1973) has termed human } \\
\text { developmental power. }\end{array}$ \\
\hline Culture: wisdom & $\begin{array}{l}\text { A culture is wise if it allows the universal sharing and co-operative } \\
\text { constitution of knowledge, ideas, values, norms, and sets standards } \\
\text { that allow literacy and the attainment of educational skills for all, } \\
\text { physical and mental health of all, the maximization of life time in health } \\
\text { for all, communicative dialogue in which all voices are heard and } \\
\text { influential, a culture of understanding that allows finding common } \\
\text { values without compromising difference (unity in diversity), the } \\
\text { experience of entertainment, beauty, the diversity of places, mental } \\
\text { challenge and diversity, physical exercise for all, and building } \\
\text { communities, relations, love, and friendships for all. }\end{array}$ \\
\hline
\end{tabular}

The dimensions of participation do not exist independently, but are interdependent, i.e. a lack of a certain dimension eventually will have negative influences on other dimensions, whereas enrichment of one dimension will provide a positive potential for the enrichment of other dimensions. So for example, people who live in poverty are likely to not show much interest in political participation. Another example is that an unsustainable ecosystem advances an unsustainable society and vice versa: If man pollutes nature and depletes non-renewable natural resources problems, i.e. if he creates an unhealthy environment, problems such as poverty, war, totalitarianism, extremism, violence, crime, etc. are more likely to occur.
The other way round a society that is shaken by poverty, war, a lack of democracy and plurality, etc. is more likely to pollute and deplete nature. So sustainability should be conceived as being based on the dialectic of ecological preservation, human-centred technology, economic equity, political freedom, and cultural wisdom.

\section{An application of critical information theory - ideology critique of information}

How people talk about certain things, i.e. which categories they use and in which situations, is framed by their worldviews, i.e. by their basic outlooks of what they consider 
good and bad, desirable and undesirable, necessary and unnecessary. These worldviews in a certain moment of society are shaped by the history of an individual's socialization patterns that have accumulated and produced certain emergent moral qualities. Morals are not static, have a potential to develop based on new socialization patterns, but they are also not fully dynamic, i.e. there is a certain continuity of morals as long as they are not shaken by experiences that transform our lives fundamentally. Our worldviews are shaped by our positions in class relations, power relations, and collective identities that are again based on the dialectic of continuity and discontinuity. Individual morals are shaped by the morals and identities of the groups that we enter continuously and they to certain degrees shape and maintain group morals and identities in recursive processes (Fuchs, 2008, chapter 3).

If worldviews shape our basic behaviour and how we confront the world, then academia is not a value-neutral system, but the academic categories, models, theories, principles and methods that we construct, use, apply, revise, and criticize are shaped by our basic world outlooks. There are reasons why we use or do not use a certain category. There are reasons why we define a category in a certain way and not in another. Therefore there are also reasons why information is defined in certain ways. Ideology critique of information means to uncover the worldviews that underlie the notion of information. For doing so, one first needs to know what an ideology actually is.

The discussion of the concept of ideology and of ideology critique has been most intensively carried out by Marxist theory. The notion was already important in the works of Marx and has been subsequently elaborated by Marxian scholars. The Marxian concept of ideology is based on a realist ontoepistemology, i.e. the grounded assumption that reality exists objectively and that academic scholars are able to describe and analyze society as it is. Grasping society as it is and as it could and should be, is seen as the foundation for judgements about worldviews, theories, and knowledge that are distorted, i.e. that claim that reality should be or can only be organized in a certain way that is different from its true actual or potential state. Ideology critique sees such claims as representations of repressive interests.

Engels argues that ideas are "reflections true or distorted - of reality" (MEW 20, p. 573). If ideas can be distorted, this means that objective reality can be represented in false, non-identical forms in consciousness. By comparing ideology to a camera obscura, Marx points out that ideology misrepresents reality so that fictive ideas are considered as primary and the world is turned on its head: "If in all ideology men and their circumstances appear upside-down as in a camera obscura, this phenomenon arises just as much from their historical life-process as the inversion of objects on the retina does from their physical life-process" (MEW 3, p. 26).

For Marx, ideology is the expression of dominant class interests and the attempt to control the dominated: "The ideas of the ruling class are in every epoch the ruling ideas, i.e. the class which is the ruling material force of society, is at the same time its ruling intellectual force. The class which has the means of material production at its disposal, has control at the same time over the means of mental production, so that thereby, generally speaking, the ideas of those who lack the means of mental production are subject to it" (MEW 3, p. 46). "Morality, religion, metaphysics, all the rest of ideology" are characterized by Marx as "phantoms formed in the human brain" (MEW 3, pp. 26f). Already in the well-known Introduction to $A$ Contribution to the Critique of Hegel's Philosophy of Right, Marx saw religion as ideology that results in "an inverted consciousness of the world" and functions as "opium of the people " (MEW 1, p. 378).

The insight that ideology distorts reality was later preserved and expanded in the chapter on the Fetishism of Commodities in Capital, Volume 1 (MEW 23, pp. 85-98). "A commodity is therefore a mysterious thing, simply because in it the social character of men's labour appears to them as an objective character stamped upon the product of that labour; because the relation of the producers to the sum total of their own labour is presented to them as a social relation, 
existing not between themselves, but between the products of their labour" (MEW 23: 86). Marx assumes that the commodity character of goods conceals that these goods exist only because they are produced by human labour in class relations. The "phantasmagoric" impression that commodity, capital, and money are natural forms of existence that do not have societal foundations would be created. Marx here again speaks of "mistenveloped regions of the religious world" (MEW 23, p. 86), his initial critique of religion is extended to capitalism in order to show that the commodity and capital forms are manipulative and distort reality. The fetish character of commodities also applies to the capitalist mass media: The forms of domination of capitalism are naturalized by the media and are portrayed as being unchangeable, it is concealed that they have a historic character, can be transformed by social struggles, and are the result of societal development and social relations.

The Hungarian philosopher Georg Lukács $(1923 / 1972)$ has argued that bourgeois ideology tries to present the existence of capitalism as an unhistorical law that cannot be changed: "The objective forms of all social phenomena change constantly in the course of their ceaseless dialectical interactions with each other. The intelligibility of objects develops in proportion as we grasp their function in the totality to which they belong. This is why only the dialectical conception of totality can enable us to understand reality as a social process. For only this conception dissolves the fetishistic forms necessarily produced by the capitalist mode of production and enables us to see them as mere illusions which are not less illusory for being seen to be necessary. These unmediated concepts, these 'laws' sprout just as inevitably from the soil of capitalism and veil the real relations between objects. They can all be seen as ideas necessarily held by the agents of the capitalist system of production. They are, therefore, objects of knowledge, but the object which is known through them is not the capitalist system of production itself, but the ideology of its ruling class. Only when this veil is torn aside does historical knowledge become possible. For the function of these unmediated concepts that have been derived from the fetishistic forms of objectivity is to make the phenomena of capitalist society appear as supra-historical essences. The knowledge of the real, objective nature of a phenomenon, the knowledge of its historical character and the knowledge of its actual function in the totality of society form, therefore, a single, undivided act of cognition" (Lukács, 1923/1972, pp. 13f).

Ideology would also be immanent in the economic forms of capitalism itself. What Marx termed the fetish character of commodities is termed reification by Lukács: "The fetishistic character of economic forms, the reification of all human relations, the constant expansion and extension of the division of labour which subjects the process of production to an abstract, rational analysis, without regard to the human potentialities and abilities of the immediate producers, all these things transform the phenomena of society and with them the way in which they are perceived" (Lukács, 1923/1972, p. 6).

The Italian Marxist Antonio Gramsci added to Marx's theory of ideology the insight that ideology is not simply imposed by dominant groups on the dominated, but that the latter also agree to domination by refusing to resist, by hoping to gain advantages by supporting domination, or by not seeing through the presented lies so that as a result they consent to their own oppression. Hegemony means in this context the "'spontaneous' consent of the masses who must 'live' those directives, modifying their own habits, their own will, their own convictions to conform with those directives and with the objectives which they propose to achieve" (Gramsci, 1971, p. 266). Louis Althusser (1971/1994) stressed that ideology is a "system of the ideas and representations which dominate the mind of a man or a social group" (p. 120) and that "ideology represents the imaginary relationship of individuals to their real conditions of existence" (p. 123). "We observe that the structure of all ideology, interpellating individuals as subjects in the name of a Unique and Absolute Subject is speculary, i.e. a mirror-structure, and doubly speculary: this mirror duplication is constitutive of ideology and ensures its functioning. Which means that all ideology is centred, that the Absolute Subject occupies the unique place of the 
Centre, and interpellates around it the infinity of individuals into subjects in a double mirrorconnexion such that it subjects the subjects to the Subject" (p. 134). For Althusser, ideologies are relations and ways of thinking, acting, believing, convincing, and coercing that do not represent reality as it is, but ideas and interests of dominative groups that want to define reality in a certain way and convince subordinate groups to see reality the same way so that they do not resist domination and their own subordination. Someone who favours a certain ideology takes part in certain practices (going to church, meetings, consumption of information and culture, etc). These practices show for Althusser that ideologies have a material existence and are not just ideas. That ideology calls human beings as subjects in the name of a higher subject (interpellation) means that ideology tries to convince or coerce an individual to believe in the superiority of a certain force (God, leader, state, boss, guru, money, market, etc) and to submit its actions and thinking to the will of this absolute subject.

The Frankfurt School has argued that with the establishment of $20^{\text {th }}$ century capitalism, the mass media and culture have taken on commodity form in a way that simplifies and distorts reality, keeps people calm by preoccupying them with light entertainment. Consciousness would become instrumental like a machine, reflection would be substituted by standardized automatic reactions so that potential alternatives to existing society would no longer be thought and would therefore become unlikely. "Each single manifestation of the culture industry inescapably reproduces human beings as what the whole has made them. And all its agents, from the producer to the women's organization, are on the alert to ensure that the simple reproduction of mind does not lead on to the expansion of mind" (Horkheimer \& Adorno, 1944/2002, p. 100). "Just as a child repeats the words of his mother, and the youngster the brutal manners of the elders at whose hands he suffers, so the giant loud-speaker of industrial culture, blaring through commercialized recreation and popular advertising - which become more and more indistinguishable from each other endlessly reduplicates the surface of reality" (Horkheimer, 1947/1974, p. 96). Herbert
Marcuse spoke in this context of the emergence of one-dimensional consciousness and as a result of a onedimensional society: "In a specific sense advanced industrial culture is more ideological than its predecessor, inasmuch as today the ideology is in the process of production itself. In a provocative form, this proposition reveals the political aspects of the prevailing technological rationality. The productive apparatus and the goods and services which it produces 'sell' or impose the social system as a whole. The means of mass transportation and communication, the commodities of lodging, food, and clothing, the irresistible output of the entertainment and information industry carry with them prescribed attitudes and habits, certain intellectual and emotional reactions which bind the consumers more or less pleasantly to the producers and, through the latter, to the whole. The products indoctrinate and manipulate; they promote a false consciousness which is immune against its falsehood. And as these beneficial products become available to more individuals in more social classes, the indoctrination they carry ceases to be publicity; it becomes a way of life. It is a good way of life - much better than before - and as a good way of life, it militates against qualitative change. Thus emerges a pattern of one-dimensional thought and behavior in which ideas, aspirations, and objectives that, by their content, transcend the established universe of discourse and action are either repelled or reduced to terms of this universe" (Marcuse, 1964b, pp. 11f).

Much more could be said about the Marxist theory of ideology (cf. the contributions in Žižek, 1994), but there is not the space to do so here and therefore the discussion needs to be confined to some key thinkers. An ideology is a process, in which dominative groups address dominated groups and individuals, at which expense they maintain privileges and control of resources, with a system of ideas that tries to justify the existing conditions and forestall change. The dominated respond to this address by reproducing it largely or partly or by neglecting it and developing alternative interpretations and ideas that guide resistance. In any case, there will be a response by the dominated in the form of material practices. It is not predetermined, but 
conditioned how these response practices look like. It is more likely that hegemonic than counter-hegemonic practices will emerge because dominant groups and individuals tend to make use of continuous structures (education, propaganda, mass media, religion, associations, etc) that try to secure a positive response. Saying yes to ideologies is easier than saying no. Successful ideologies produce and reproduce false consciousness, i.e. a state of mind that considers conditions that favour the one at the expense of the others as acceptable. True consciousness in contrast is one that aims at conditions from which all benefit. Such a state can also be described as the condition of participatory democracy (Macpherson, 1973).

Ideologies operate in one of the following ways:

- Reduction of problems to underprivileged persons or groups of persons or single subsystems: Single subsystems of society or underprivileged groups that are themselves victims of the system are presented as the causes of problems, which implies that they should be eliminated. Problems are reduced to persons or other particularistic entities in order to forestall changing the true causes. This is for example the logic of racism. Higher complexity and interconnection of singularities to other phenomena and systems are ignored.

- Reductionistic fetishism: Things are presented as solutions for problems so that the underlying social relations that produce and reproduce these things are ignored (fetishism). Problem solutions are reduced to things. This is for example the case in technological determinism (technologies are presented as problem solvers) or consumerism (the idea of shopping and the promise of owning commodities is presented as liberating and as source of happiness).

- Holistic automatism: Problems are presented as non-problems by trying to install a belief in the inner development of the existing system towards frictionless development. It is assumed that the system always has the capacity to solve its own problems, that one should just wait and do nothing, and that there can be no breakdown. The logic of neoliberalism that is based on the belief that markets are the best way of organizing all aspects of economy and society is an example.

- Dualistic denouncement or denial of possible alternatives: Existing society is presented as the best possible society. In a dualistic sense the possible future is split off from the present as unthinkable or unrealizable. Certain developments are not considered likely or simply ignored.

- Dualistic pluralization: Various goals are postulated without seeing that they might conflict. Multiple causalities are applied that are separated and not connected to each other.

- There can be any combination of these elements.

Based on this notion of ideology, some first, preliminary, non-conclusive aspects of the ideology critique of information can be outlined. For Lukács, legitimatizing reification (Verdinglichung, treating somebody like a thing or relegating him or her to the status of a thing) and the effects of reification on consciousness (false consciousness) are the central ideological processes. Reification means "that a relation between people takes on the character of a thing and thus acquires 'phantom objectivity', an autonomy that seems so strictly rational and all-embracing as to conceal every trace of its fundamental nature: the relation between people" (Lukács, $1923 / 1972$, p. 83). Objective notions of information, such as the classical ShannonWeaver model, see information as a thing that can be treated in certain ways. It can be no accident that such a definition has become the mainstream model of information in the Western world during the $20^{\text {th }}$ century. If information is seen as a thing, then it is obvious to argue that it should be treated as a commodity. Just like humans, who sell their labour power as commodities, milk that is sold in a shop, cars that are sold by car dealers, or stocks that are sold on financial markets. The objective notion of information is the foundation of the rise of information technologies (IT) that are based on the computer and therefore on binary logic. IT has 
become an important commodity itself, and a medium of advertisement for commodities, and the selling and transport of information commodities. Therefore information in its IT form is close to the commodity form and has therefore undergone a process of reification that can also be termed commodification (Fleissner 2006). Commodification, i.e. the treatment of social relations as commodities, certainly is not the only type of reification today. One can for example see rape, warfare, media manipulation, racism and xenophobia, etc. as other forms. But commodification is certainly a central form of reification, with which all other forms of reification are articulated. The logic of technological determinism that argues that there are technological fixes to societal problems, is an expression of reified consciousness.

The very logic of IT is itself one of reification: Computers are based on mechanistic logic. Each input produces an exactly determined output. Computers do not have freedom of action, there is no chance and indeterminacy in binary logic. Computers are undialectical systems. They know no blurring of boundaries, just the logic of either/or. Dialectical logic in contrast operates based on the logic both/and. The computer could therefore also be seen as a reified system, one that is based on technological rationality and instrumental reason. The danger in speaking of a computerized society, an information society, a virtual society, a cybersociety, a digital society, or an IT society is that we reify society itself, that the metaphors of IT or the computer result in a generalization of the undialectical qualities of the computer to society. Lukács (1923/1972, p. 89) sees calculability as a central aspect of reification processes. In such processes, humans have to function like parts of a machine (Lukács, 1923/1972, p. 89). Each time when humans are reified, for example if they are manipulated by the media or have to sell their labour power in order to survive processes that were described with the category of instrumental reason by Horkheimer and Adorno (1944/2002) and the category of undialectical one-dimensionality by Marcuse (1964b) - , we could also say that humans are computerized, they are reduced to the status of things. The logic of the computer - its strict instrumental separation generalized to society is a process of establishing fascism. In a provocative manner one could therefore say that fascism is inscribed into the computer and in order to avoid a fascist society we need political regulation of society that avoids negative effects of computer usage on society. In an even more provocative way, one could say that the computer scientist is the prototype of instrumental reason and therefore always a potential (but not necessarily an actual) fascist. In order to avoid the realization of these fascist potentials, ethical, normative, critical thinking is needed already in the education of computer scientists. The mass extermination of Jews in extermination camps like Auschwitz is the ultimate form of reification - the treatment of humans no longer as human, but as things that can be arbitrarily used, abused, and killed. Horkheimer and Adorno (1944/2002) argued that Auschwitz is the ultimate result of the modern unfolding of instrumental reason. If instrumental reason is also the immanence of the computer, then also Auschwitz is potentially inside of the logic of the digital machine, but not only there. Auschwitz constructed a terroristic binary either/or: Jew/Aryan - dead or alive. Auschwitz itself was a giant negative machine, a machine of destruction of humans based on digital logic. Auschitz is the ultimate digital machine of capitalist society. Auschwitz is the computer of modernization. Defining information as thing advances foundations of reifying information and as effect also the reification of humans. Such definitions should therefore be considered as being ideologies. Lukács (1923/1972, p. 100) stressed that reification of information is an aspect of the reification of humans and society. Reification "stamps its imprint upon the whole consciousness of man; his qualities and abilities are no longer an organic part of his personality, they are things which he can 'own' or 'dispose of' like the various objects of the external world" (Lukács, 1923/1972, p. 100).

If we want to avoid a second Auschwitz, then we certainly need not abolish information technology, but we need to shape society and techno-social systems in ways that avoid the 
reification of humans and establish a new form of rationality that is based on the notion of co-operation, a logic in which all benefit. The information society is in its capitalistic form (informational capitalism) a highly instrumental society. Therefore a second Auschwitz might be dawning and needs to be circumvented by all means. Exclusion, oppression, exploitation, warfare are omnipresent and ubiquitous in contemporary society. These phenomena can turn into massive projects of repression. Information and information technology are functional parts of repression (Fuchs 2008). The precondition for establishing a humane society is that we put an end to reification. The end of reification is at the same time certainly the end of class society and capitalism.

A second type of definition of information is the subjective one. The most prominent subjectivist approach in my opinion is radical constructivism that sees all knowledge as strictly individually constructed. Radical constructivism is therefore based on the worldview of individualism. Individualism is also the ideology that underlies bourgeois society in the form of the notion of private property of the means of production. This fundamental bourgeois human right conflicts with another human right, the one of equality. Capital accumulation has again and again resulted in socio-economic inequality, as the history of capitalism has shown. If you consider knowledge as an individual creation, you are bound to celebrate individual creativity. A standard legal argument is that individual inventions and creativity need to be protected by property laws. If knowledge is considered as individual creation, then the call for intellectual property rights that make sure that knowledge is treated as commodity that is sold on markets in order to generate money profit, can easily be legitimated. In the end, subjectivist notions of information turn out to be ideologies that legitimate private property and the commodity form of information. Information is reified to the status of a commodity. Therefore subjectivist notions of information should be seen as being ideological.

A non-reifying notion of information is neither objectivist nor subjectivist. If we consider information as subject-objectdialectic, then it is a dynamic processual relation between agents. In human society, it must then be considered as social coproduction and co-operation process that transforms systems. If social information is always produced by many interacting humans, then there is no natural or moral owner of it. Knowledge is a social, cooperative good. New knowledge is based on old, historical knowledge. Those who produce novel qualities of knowledge stand on the shoulders of giants and use the prior history of all knowledge for free in order to add something new. If there is no owner of knowledge, then it must be considered as a commons, an aspect of society that is needed for its existence and reproduction and should therefore not be limited or restricted in order to guarantee the reproduction of society and humans to a full extent. Reifying knowledge, treating it as commodity or limiting it in another way, means to partly destroy the commons of society and therefore basic necessary resources of society. Reifying knowledge is unjust because it gives certain individuals and groups (who for example have more money) more control of knowledge so that they can derive material benefits from the usage of knowledge, it is undemocratic because it restricts knowledge production and access to certain groups and individuals and excludes others, and it is a form of misrecognition because it denies people knowledge that could be important for creating change, new insights or worldviews. But not just limiting access is ideological, also providing false, useless, unnecessary, stupefying, manipulative knowledge is a form of ideology that is unjust, undemocratic, and an expression of malrecognition.

If we consider the essence of information as social, historical, co-operative process, then reifying information is normatively false. The reification of information should therefore be practically criticized in social struggles. The idea of knowledge as commons anticipates a non-reified, non-commodified, non-dominative society, in which humans are treated as true humans and not as things. Communist information ethics not only allow us to imagine a world without reification, but also to free the ideas of revolution, rebellion, and 
expropriation of the expropriators from the continuum of ideological repression. It allows us to discuss and consider alternatives to capitalism and the insight that capitalism is not the end of history. To discuss information without ideology critique and to neglect reification processes of information are historical mistakes that are characteristic for the contemporary "information age". Therefore this capitalistic information age is one of reified consciousness, one that is in danger of creating its own Auschwitz of the information age.

One could interpose that my approach is ideological too because it implies that capitalism must be abolished in order to realize a participatory society, which could be seen as a political project. But first, all academic knowledge is influenced by certain political values and goals, although some scholars tend to argue that a value-neutral objective academic is possible. It is honest to actively admit that there are moral and political questions that influence knowledge production. Immanuel Wallerstein (2007) argues that all social science has an intellectual, a moral, and a political function and that all social scientists are always doing all three functions. The ideology of instrumental positivistic sciences is that they deny the second and the third function, whereas critical theory deconstructs this ideology, they are partisan in favour of the oppressed. Their partisanship is active. All three functions "are always being done, whether actively or passively. And doing them actively has the benefit of honesty and permitting open debate about substantive rationality" (Wallerstein, 2007, p. 174). Second, the notion of ideology has mainly been used in Marxian theory. And within this theoretical framework, ideology is a necessary "inverted consciousness of the world" (MEW 1 , p. 378), a worldview necessary for society to legitimize injustice, oppression, and domination. Ideology is the "universal basis of consolation and justification" as long as "the human essence has not acquired any true reality" (MEW 1, p. 378). This notion of ideology presupposes that humans are able to analyze and realize the potentials of societal development, to give a realistic picture of society as it is and as it could be, and to find ways to install a society, in which all humans benefit. If humans are able to engage in such a realistic epistemology, then a false state of society is one, in which the one have advantages at the expense of others. Such false states can be laid open and analyzed. Those who benefit from the falseness of society have false consciousness and tend to create worldviews that aim at reproducing the falseness of society and the corresponding states of mind. A true state of society is one where all benefit. Therefore a distinction between false and true consciousness can be made. Only false consciousness is designated as being ideological. The immanent and unrealized essence of society is participatory democracy (Macpherson, 1973), a state in which all benefit and co-operate.

\section{Conclusion}

The main argument of this work is that we need to be careful in how we define information. We should actively engage in uncovering and talking about the worldviews and political projects that underlie information concepts. It was suggested that the notion of critique should not just be understood as asking questions, but as deriving domination of its ideological and material foundations. Critique means working for the destruction of reification and towards the creation of a nonreified, co-operative, participatory world. Information theory can be part of this project by becoming critical information theory.

Remember the example of IBM and the Nazis that was introduced at the very beginning of this work. It showed that media and communication are implicated in systems of domination such as the Nazi regime. IBM sold communication systems to the Nazis as commodities for gaining profits. The Nazis made use of media such as the singlechannel radio known as the Volksempfänger, for diffusing their fascist ideology. Resistance groups, which were primarily communist in nature, tried to make use of alternative media such as critical leaflets, post cards, or papers that they had to create, print, and distribute all by themselves. In order to find out what was really going on in the war and to escape the manipulated Nazi propaganda, some Austrians and Germans adopted the 
alternative reception practice of listening illegally to BBC. Cases have been documented that show that penal servitude was used as punishment for listening to what was termed "Feindpropaganda" (enemy propaganda). So for example, the Viennese janitor Leopoldine Amort was sentenced to 18 months penitentiary in maximum-security prison on April 25, 1942 for the "crime of listening to foreign radio stations and propagating news reports of foreign radio stations" ${ }^{\prime \prime}$. An excerpt from the verdict against three communist resistance fighters reads: "The defendants [Ferdinand] Kosztelny, Anderst and [Johann] Fried have paid membership fees to the Communist Party of Austria up to and beyond the beginning of the military campaign against the Bolsheviks. Furthermore they have distributed subversive pamphlets and have (except Kosztelny) courted like-minded persons for the payment of contributions. Therefore they are sentenced to death and lifelong loss of civil rights

\footnotetext{
5 Documentation Centre of Austrian Resistance, Database of Gestapo Victims,

$<$ http://de.doew.braintrust.at/gestapoopferdb.html>, accessed on August 19, 2008
}

because of subversive activities"6. Ferdinand Anderst, Johann Fried, and Ferdinand Kosztelny were executed on October 221943 at the Regional Court Vienna.

Karl Marx defined critique as "the categoric imperative to overthrow all relations in which man is a debased, enslaved, abandoned, despicable essence" (MEW 1, p. $385^{7}$ ). The examples just given should have shown that information is implicated in domination and that therefore the Marxian categoric imperative is important. Critical information theory is only critical if it is a Marxian theory, which means that it is a theory that provides conceptual means that can guide potential struggles for a non-reified world.

6 Ibid. "Die Angeklagten [Ferdinand] Kosztelny, Anderst und [Johann] Fried haben bis in die Zeit des Feldzuges gegen die Bolschewisten hinein für die KPÖ Mitgliedsbeiträge gezahlt und einkassiert. Sie haben ferner staatsfeindliche Flugschriften verbreitet und bis auf Kosztelny andere Gesinnungsgenossen für die Beitragszahlung geworben. Sie werden deshalb und wegen sonstiger staatsfeindlicher Betätigung zum Tode und zum Ehrenrechtsverlust auf Lebensdauer verurteilt".

${ }^{7}$ Translation from:

<http://www.marxists.org/archive/marx/works/1843/critiqu e-hpr/intro.htm> (accessed on September 30, 2008).

\section{References}

Adorno, Theodor W. (1962). Zur Logik der Sozialwissenschaften. In Soziologische Schriften I (pp. 574-585). Frankfurt/Main: Suhrkamp.

Adorno, Theodor W. (1969). Einleitung zum "Positivismusstreit in der deutschen Soziologie". In Soziologische Schriften I (pp. 280-353). Frankfurt/Main: Suhrkamp.

Althusser, Louis (1971/1994). Ideology and ideological state apparatuses. In Slavoj Zizek (Ed.), Mapping ideology (pp. 100140). London: Verso.

Bhaskar, Roy (1993). Dialectic: The pulse of freedom. London: Verso.

Best, Steven \& Kellner, Douglas (1991). Postmodern theory: Critical investigations. New York: Guilford Press.

Black, Edwin (2001). IBM and the holocaust: The strategic alliance between nazi Germany and America's most powerful corporation. New York: Crown.

Bloch, Ernst (1959). Das Prinzip Hoffnung. Frankfurt/Main. Suhrkamp.

Bonß, Wolfgang (2003). Warum ist die Kritische Theorie kritisch? Anmerkungen zu alten und neuen Entwürfen. In Alex Demirovic (Ed.), Modelle kritischer Gesellschaftstheorie (pp. 366-390). Stuttgart: J.B. Metzler.

Bourdieu, Pierre (1986). The (three) forms of capital. In John G. Richardson (Ed.), Handbook of theory and research in the sociology of education (pp. 241-258). New York: Greenwood Press.

Burawoy, Michael (2000). Marxism after communism. Theory and Society, 29(2), 151-174.

Burawoy, Michael, \& Olin Wright, Erik (2002). Sociological Marxism. In Jonathan H. Turber (Ed.), Handbook of sociological theory (pp. 459-486). New York: Kluwer.

Burawoy, Michael (2005a). Rejoinder: Toward a critical public sociology. Critical Sociology, 31(3), 379-390.

Burawoy, Michael (2005b). The critical turn to public sociology. Critical Sociology, 31(3), 314-326.

Burawoy, Michael (2007). For public sociology. In Dan Clawson, Robert Zussman, Joya Misra, Naomi Gerstel, Randall Stokes, Douglas L. Anderton, \& Michael Burawoy (Eds.), Public sociology (pp. 23-64). Berkeley, CA: University of California Press. 
Burbules, Nicholas C., \& Berk, Rupert (1999). Critical thinking and critical pedagogy: Relations differences, and limits. In Thomas S. Popkewitz and Lynn Fendler (Eds.), Critical theories in education (pp. 45-65). New York: Routledge.

Butler, Judith (1990). Gender trouble: Feminism and the subversion of identity. New York: Routledge.

Calhoun, Craig (1995). Critical social theory. Cambridge, MA: Malden.

Callinicos, Alex (2003). An anti-capitalist manifesto. Cambridge, UK: Polity.

Callinicos, Alex (2006). The resources of critique. Cambridge, UK: Polity.

Callinicos, Alex (2007). Social theory. Cambridge, UK: Polity.

Deleuze, Gilles (1995). Postscript on the societies of control. In Negotiations (pp. 177-182). New York: Columbia University Press.

Deleuze, Gilles (2001). Pure immanence. New York: Zone Books.

Demirovic, Alex (2003a). Kritische Gesellschaftstheorie und Gesellschaft. In Alex Demirovic (Ed.), Modelle kritischer Gesellschaftstheorie (pp. 10-27). Stuttgart: J.B. Metzler.

Demirovic, Alex (2003b). Vorwort. In Alex Demirovic (Ed.), Modelle kritischer Gesellschaftstheorie (pp. 1-9). Stuttgart: J.B. Metzler.

Demirovic, Alex (2004a). Der Zeitkern der Wahrheit. Zur Forschungslogik kritischer Gesellschaftstheorie. In Joachim Beerhorst, Alex Demirovic, \& Michael Guggenmos (Eds.), Kritische Theorien im gesellschaftlichen Strukturwandel (pp. 475-499). Frankfurt/Main: Suhrkamp.

Demirovic, Alex (2004b). Vorwort. In Joachim Beerhorst, Alex Demirovic, \& Michael Guggenmos (Eds.), Kritische Theorien im gesellschaftlichen Strukturwandel (pp. 7-13). Frankfurt/Main: Suhrkamp.

Demirovic, Alex (2007). Arche Noah: Zur Aktualität der kritischen Gesellschaftstheorie. In Rainer Winter \& Peter V. Zima (Eds.), Kritische Theorie heute (pp. 67-78). Bielefeld: transcript.

Derrida, Jacques (1994). Specters of Marx. New York: Routledge.

Dyer-Witheford, Nick (1999). Cyber-Marx. Cycles and circuits of struggle in high-technology capitalism. Urbana, IL: Universiy of Illinois Press.

Ennis, Robert H., \& Weir, Eric (1985). The Ennis-Weir critical thinking essay test. Pacific Grove, CA: Midwest Publications.

Facione, Peter A., Giancarlo, Carol A., Facione, Noreen C., \& Gainen, Joanne (1995). The disposition toward critical thinking. Journal of General Education, 44 (1), 1-25.

Fleissner, Peter (2006). Commodification, information, value and profit. Poiesis \& praxis, International Journal of Technology Assessment and Ethics of Science, 4(1). 39-53.

Foucault, Michel (1977). Nietzsche, genealogy, history. In Donald F. Bouchard (Ed.), Language, counter-memory, practice: Selected essays and interviews (pp. 139-164). Ithaca: Cornell University Press.

Foucault, Michel (2002). The archaeology of knowledge. Oxon: Routledge.

Fox Piven, Francis (2007). From public sociology to politicized sociologist. In Dan Clawson, Robert Zussman, Joya Misra, Naomi Gerstel, Randall Stokes, Douglas L. Anderton, \& Michael Burawoy (Eds.), Public sociology (pp. 158-166). Berkeley, CA: University of California Press.

Fraser, Nancy. (1985). What's critical about critical theory? The case of Habermas and gender. New German Critique, 35 (Spring/Summer 1985), 97-131.

Fraser, Nancy \& Honneth, Axel (2003). Redistribution or recognition? A political-philosophical exchange. London: Verso.

Fuchs, Christian (2005). Emanzipation! Technik und Politik bei Herbert Marcuse. Aachen: Shaker.

Fuchs, Christian (2006). The dialectic of the nature-society-system. tripleC, 4(1), 1-39.

Fuchs, Christian (2008). Internet and society: Social theory in the information age. New York: Routledge.

Fuchs, Christian (2009). Information and communication technologies \& society: A contribution to the critique of the political economy of the internet. European Journal of Communication, 24(1), 69-87.

Giancarlo, Carol A. and Peter A. Facione (2001). A look across four years at the disposition toward critical thinking among undergraduate students. Journal of General Education, 50 (1), 29-55.

Giddens, Anthony (1984). The constitution of society. Outline of the theory of structuration. Cambridge: Polity Press.

Giroux, Henry A. (1994). Toward a pedagogy of critical thinking. In Kerry S. Walters (Ed.), Re-Thinking reason: New perspectives in critical thinking (pp. 200-201). Albany: SUNY.

Gramsci, Antonio (1971). Selections from the prison notebooks. New York: International Publishers.

Habermas, Jürgen (1981). Theorie des kommunikativen Handelns. 2 vols. Frankfurt/Main: Suhrkamp.

Hall, Stuart. (1983) The problem of ideology: Marxism without guarantees. In Betty Metthews (Ed.), Marx: A hundred years on (pp. 57-84). London: Lawrence \& Wishart.

Hames-García, Michael. (2001) Can queer theory be critical theory? In William S. Wilkerson \& Jeffrey Paris (Eds.), New critical theory (pp. 201-222). Lanham: Rowman \& Littlefield.

Hardt, Michael \& Negri, Antonio (2000). Empire. Cambridge, MA: Harvard University Press.

Hardt, Michael \& Negri, Antonio (2005). Multitude. London: Hamish Hamilton.

Harvey, David (2003). The new imperialism. Oxford: Oxford University Press.

CC: Creative Commons License, 2009. 
Harvey, David (2005). A brief history of neoliberalism. Oxford: Oxford University Press.

Hegel, Georg Wilhelm Friedrich (1830). Enzyklopädie der philosophischen Wissenschaften im Grundrisse. Erster Teil: Die Wissenschaft der Logik. Frankfurt/Main: Suhrkamp.

Hitler, Adolf (1925). Mein Kampf Volume 1. München: Eher.

Hofkirchner, Wolfgang (2002). Projekt Eine Welt. Oder Kognition Kommunikation Kooperation. Versuch über die Selbstorganisation der Informationsgesellschaft. Münster: LIT.

Hofkirchner, Wolfgang, Fuchs, Christian, \& Klauninger, Bert (2005). Informational universe. A praxeo-onto-epistemological approach. In Eeva Martikainen (Ed.), Human approaches to the universe (pp. 75-94). Helsinki: Luther-AgricolaSeura.

Holz, Hans Heinz (2005). Weltentwurf und Reflexion: Versuch einer Grundlegung der Dialektik. Stuttgart: J.B. Metzler.

Honneth, Axel (1992). Integrity and disrespect: Principles of a conception of morality based on the theory of recognition. Political Theory, 20(2), 187-201.

Honneth, Axel (2007). Pathologien der Vernunft: Geschichte und Gegenwart der Kritischen Theorie. Frankfurt/Main: Suhrkamp.

Horkheimer, Max (1937/2002). Traditional and critical theory. In Critical theory (pp. 188-252). New York: Continuum.

Horkheimer, Max. (1947/1974). Eclipse of reason. New York: Continuum.

Horkheimer, Max, \& Adorno, Theodor W. (1944/2002). Dialectic of enlightenment. New York: Seabury.

Hoy, David C., \& McCarthy, Thomas (1994). Critical theory. Malden, MA: Blackwell.

Hoy, David C. (2004). Critical resistance. From poststructuralism to post-critique. Cambridge, MA: MIT Press.

Karatani, Kojin (2003). Transcritique. On Kant and Marx. Cambridge, MA: MIT Press.

Lash, Scott (2006). Dialectic of information? Information, Communication, and Society, 9(5), 572-581.

Lash, Scott (2002). Critique of information. London: Sage.

Lazarsfeld, Paul F. (1941/2004). Administrative and critical communications research. In John Durham (Ed.), Mass communication and American social thought: Key texts, 1919-1968, ed. John Durham (pp. 166-173). Lanham: Rowman \& Littlefield.

Luhmann, Niklas (1984). Soziale Systeme. Frankfurt/Main: Suhrkamp.

Lukács, Georg (1923/1972). History and class consciousness. Cambridge, MA: MIT Press.

Lukes, Steven (1985). Marxism and morality. Oxford: Oxford University Press.

Lyotard, Jean-Francois (1979). The postmodern condition. Manchester: Manchester University Press.

Macpherson, Crawford Brough (1973). Democratic theory: Essays in Retrieval. Oxford: Clarendon Press.

Marcuse, Herbert (1932). Neue Quellen zur Grundlegung des Historischen Materialismus. In Schriften, Volume 1 (pp. 509555). Frankfurt/Main: Suhrkamp.

Marcuse, Herbert (1937a). The Concept of Essence. In Negations: Essays in Critical Theory (pp. 43-87). London: Free Association.

Marcuse, Herbert (1937b). Philosophie und kritische Theorie. In Schriften, Volume 3 (pp. 227-249). Frankfurt/Main: Suhrkamp.

Marcuse, Herbert (1941). Reason and revolution. Hegel and the rise of social theory. New York: Humanity Books.

Marcuse, Herbert (1958). Soviet Marxism. New York: Columbia University Press.

Marcuse, Herbert (1964a). Ethik und Revolution. In Schriften, Volume 8 (pp. 100-114). Frankfurt/Main: Suhrkamp.

Marcuse, Herbert. (1964b). One-dimensional man. New York: Routledge.

Marcuse, Herbert. (1968). The concept of essence. In Negations (pp. 43-87). Boston: Beacon Press.

Marsh, James L. (2001). Toward a new critical theory. In William Wilkerson \& Jeffrey Paris (Eds.), New critical theory (pp. 49-64). Lanham: Rowman \& Littlefield.

Marx, Karl \& Engels, Friedrich (MECW). Collected works. New York: International Publishers.

Marx, Karl \& Engels, Friedrich (MEW). Werke. Berlin: Dietz.

Matustik, Martin Beck. (2001). Foreword. In Wilkerson, William S. \& Paris, Jeffrey (Eds.), New critical theory (pp. vii-xiii). Lanham: Rowman \& Littlefield.

McChesney, Robert W. (2007). Communication revolution. Critical junctures and the future of media. New York: The New Press.

Meehan, Eileen R. (1999). Commodity, culture, common sense. Media research and paradigm dialogue. Journal of Media Economics, 12(2), 149-163.

Murdock, Graham, \& Golding, Peter (2005). Culture, communications and political economy. In James Curran \& Michael Gurevitch (Eds.), Mass media and society (pp. 60-83). New York: Hodder Arnold.

O'Connor, James (1998). Natural causes. Essays in ecological marxism. New York: Guilford.

Paris, Jeffrey (2001). Obstinate critique and the possibility of the future. In William S. Wilkerson \& Jeffrey Paris (Eds.), New critical theory (pp. 15-36). Lanham: Rowman \& Littlefield. 
Popper, Karl R. (1962). Zur Logik der Sozialwissenschaften. Kölner Zeitschrift für Soziologie und Sozialpsychologie, 14(2), 233-248.

Rasmussen, David M. (1999). Critical theory and philosophy. In David M. Rasmussen (Ed.), The handbook of critical theory (pp. 11-38). Malden, MA: Blackwell.

Rosenberg, Alfred (1930). Der Mythus des zwanzigsten Jahrhunderts. München: Hoheneichen.

Rorty, Richard (1998). Against unity. The Wilson Quarterly, 22, 28-38

Sayers, Sean (1997). Progress and social criticism. The european legacy: Towards new paradigms, 2 (3), 554-559.

Smythe, Dallas W. (1981/2006). On the audience commodity and its work. In Meenakshi Gigi Durham \& Douglas M. Kellner (Eds.), Media and cultural studies KeyWorks (pp. 230-256). Malden, MA: Blackwell.

Smythe, Dallas W., \& Van Dinh, Tran (1983). On critical and administrative research: A new critical analysis. Journal of Communication, 33(3), 117-127.

Tallack, Douglas (1995). Critical theory. A reader. New York: Harvester Wheatshead.

Taylor, Paul A. (2006). Putting the critique back into a critique of information. Information, Communication \& Society, 9(5), 553-571.

Tyson, Lois (2006). Critical theory today. New York: Routledge.

Vaki, Fotini (2005). Adorno contra Habermas. The Claims of Critical Theory as Immanent Critique. Historical Materialism, 13(4), 79-120.

Wallerstein, Immanuel. (2007). The sociologist and the public sphere. In Dan Clawson, Robert Zussman, Joya Misra, Naomi Gerstel, Randall Stokes, Douglas L. Anderton, \& Michael Burawoy (Eds.), Public sociology (pp. 169-175). Berkeley, CA: University of California Press.

Wilkerson, William S., \& Paris, Jeffrey (2001). New critical theory. Lanham: Rowman \& Littlefield.

Winter, Rainer (2007). Kritische Theorie jenseits der Frankfurter Schule? Zur aktuellen Diskussion und Bedeutung einer einflussreichen Denktradition. In Rainer Winter \& Peter V. Zima (Eds.), Kritische Theorie heute (pp. 23-46). Bielefeld: transcript.

Williams, Raymond (2001). The Raymond Williams reader, ed. John Higgins. Oxford/Malden: Blackwell.

Wood, Ellen Meiksins (2003). Empire of capital. London: Verso.

Zizek, Slavoj (Ed.) (1994). Mapping ideology. London: Verso.

Zizek, Slavoj (2008). In defense of lost causes. London: Verso.

\section{About the Author}

Christian Fuchs

Christian Fuchs is associate professor at the University of Salzburg. He holds a venia docendi in the research field information and communication technologies \& society. His interests are: critical theory, social theory, information society studies, critique of the political economy of media, communication, information, technology, and culture. He is author of more than 100 academic publications, including the monograph "Internet and Society: Social Theory in the Information Society" (New York: Routledge 2008). He recently published a study about social networking sites and surveillance (Fuchs, Christian. 2009. Social Networking Sites and the Surveillance Society. A Critical Case Study of the Usage of studiVZ, Facebook, and MySpace by Students in Salzburg in the Context of Electronic Surveillance. Salzburg/Vienna: Research Group UTI)

Website: http://fuchs.icts.sbg.ac.at, http://fuchs.uti.at 